$12-1-2000$

\title{
Deference and Disability Discrimination
}

Rebecca H. White

University of Georgia School of Law, rhwhite@uga.edu

Depress

\section{Repository Citation}

Rebecca H. White, Deference and Disability Discrimination (2000),

Available at: https://digitalcommons.law.uga.edu/fac_artchop/318

This Article is brought to you for free and open access by the Faculty Scholarship at Digital Commons @ University of Georgia School of Law. It has been accepted for inclusion in Scholarly Works by an authorized administrator of Digital Commons @ University of Georgia School of Law. Please share how you have benefited from this access For more information, please contact tstriepe@uga.edu. 


\title{
DEFERENCE AND DISABILITY DISCRIMINATION
}

\author{
Rebecca Hanner White*
}

TABLE OF CONTENTS

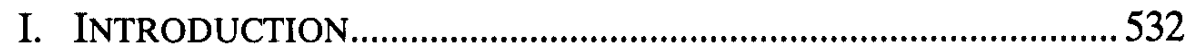

II. THE VARIOUS PERMUTATIONS OF DEFERENCE .......................539

III. THE EEOC AND THE AMERICANS WITH DISABILITIES

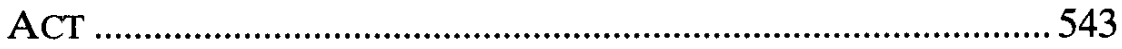

A. Chevron and the EEOC......................................................5 543

1. The Title VII Background ......................................545

2. Deference to the EEOC Under the ADEA ..........548

3. Deference to the EEOC Under the ADA ..............549

B. Defining the ADA's Protected Class ......................................553

C. Bragdon v. Abbott: Judicial Deference to Agency Interpretation Under the ADA? ...........................................55

D. Sutton v. United Air Lines and the "Mitigating Measures" Puzzle: No Deference Extended .......................559

IV. THE SUTTON COURT'S APPLICATION OF CHEVRON ………....... 563

V. THE POLITICS OF EMPLOYMENT DISCRIMINATION AND THE IMPACT ON CHEVRON ………..............................................5 569

A. Administrative Agencies, Civil Rights, and Chevron..........570

B. Chevron's Step One: A Kind of Nondelegation

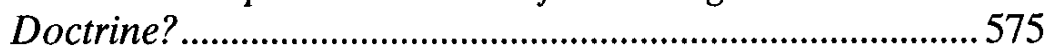

VI. DEFERENCE AND DISABILITY DISCRIMINATION:

RETHINKING SUTTON V. UNITED AIR LINES

A. The Definition of Disability: Did Congress Delegate Interpretive Authority to the EEOC?..................................578

B. The Question of Format ....................................................58

C. The Seminole Rock Claim.................................................584

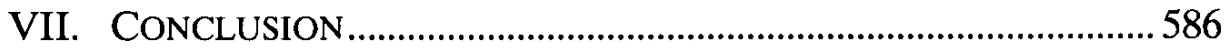

\section{INTRODUCTION}

For thirty-five years, the civil rights community has paid scant attention to administrative law principles. Those interested in advancing on-the-job equality for this country's working men and women (or in

* J. Alton Hosch Professor of Law, University of Georgia. - Ed. I thank Bob Brussack, Anne Dupre, and Dan White for their comments on this piece. I also thank my research assistant, Melissa Malcom, for her work. 
preserving employer autonomy vis-à-vis federal encroachment) have all but ignored what many consider the arcane technicalities of administrative law.

This state of affairs is strange when one considers that administration and enforcement of each of our major federal laws outlawing employment discrimination have been confided to an administrative agency, the Equal Employment Opportunity Commission ("EEOC")." The EEOC, however, has historically been given short shrift by litigants and by the judiciary. ${ }^{2}$ It is the courts, not the agency, that have given meaning to our nation's employment discrimination statutes. ${ }^{3}$

This is an unfortunate result for those who believe that political accountability and agency expertise matter in determining the meaning of indeterminate statutes. And it is a result at odds with developments in administrative law that, at least since 1984, have ostensibly required courts to pay close attention to the views of agencies charged with the administration of statutory regimes. ${ }^{4}$

1. Age Discrimination in Employment Act of $1967 \S \S 7,9,29$ U.S.C. $\$ \S 626,628$ (1994); Civil Rights Act of $1964 \S \S 705-707,709-711,713,42$ U.S.C. $\$ \S 2000 \mathrm{e}-4$ to $-6,2000 \mathrm{e}-8$ to -10 , 2000e-12 (1994); Americans with Disabilities Act of $1990 \S \S 106-07$, 42 U.S.C. $\$ \S 12116-17$ (1994).

2. See Rebecca Hanner White, The EEOC, the Courts, and Employment Discrimination Policy: Recognizing the Agency's Leading Role in Statutory Interpretation, 1995 UTAH L. REV. 51, 56 (1995) (noting sources describing the EEOC as "toothless" and a "poor, enfeebled thing" as compared to other administrative agencies). For an extended discussion of the EEOC's creation and enforcement powers, see HUGH DAVIS GRAHAM, THE CIVIL RIGHTS ERA 129-59 (1990).

3. The Supreme Court has sent conflicting signals on the deference the EEOC is due under Title VII. Compare EEOC v. Arabian Am. Oil Co., 499 U.S. 244 (1991), with EEOC v. Commercial Office Prod. Co., 486 U.S. 107 (1988). Until recently, the question of judicial deference to the EEOC's interpretations of the statutes it administers arose only infrequently in the lower courts. See Jones v. Am. Postal Workers Union, 192 F.3d 417, 427 (4th Cir. 1999); Garcia v. Spun Steak Co., 998 F.2d 1480, 1489 (9th Cir. 1993), cert. denied, 512 U.S. 1228 (1994); Rowe v. Sullivan, 967 F.2d 186, 192-94 (5th Cir. 1992); Vogel v. City of Cincinnati, 959 F.2d 594, 598 (6th Cir. 1992), cert. denied, 506 U.S. 827 (1992); Colgan v. Fisher Scientific Co., 935 F.2d 1407, 1421 n.11 (3d Cir. 1991), cert. denied, 502 U.S. 941 (1991); Philbin v. Gen. Elec. Capital Auto Lease, Inc., 929 F.2d 321, 323-25 (7th Cir. 1991); Russell v. Microdyne Corp., 830 F. Supp. 305, 308 (E.D. Va. 1993), reversed on other grounds, 65 F.3d 1229 (4th Cir. 1995). For discussions of the level of deference extended to EEOC under Title VII, see White, supra note 2; John S. Moot, Comment, An Analysis of Judicial Deference to EEOC Interpretative Guidelines, 1 ADMIN. L.J. AM. U. 213 (1987); Theodore W. Wern, Note, Judicial Deference to EEOC Interpretations of the Civil Rights Act, the ADA, and the ADEA: Is the EEOC a Second Class Agency?, 60 OHIO ST. L.J. 1533 (1999).

4. Chevron U.S.A., Inc. v. Natural Res. Def. Council, Inc., 467 U.S. 837 (1984), established the following two-step approach to judicial review of agency interpretations of statutes:

First, always, is the question whether Congress has directly spoken to the precise question at issue. If the intent of Congress is clear, that is the end of the matter; for the court, as well as the agency, must give effect to the unambiguously expressed intent of Congress. If, however, the court determines Congress has not directly addressed the precise question at issue, the Court does not simply impose its own construction on the statute, as would be necessary in the absence of an administrative interpretation. Rather, if the statute is silent or ambiguous with respect to the specific issue, the question for the court is whether the agency's answer is 
But in 1999, the question of deference to the EEOC grabbed the spotlight. It surfaced in a case ${ }^{5}$ that arose under the Americans with Disabilities Act of 1990 (the "ADA"), a relatively new, and sweeping, anti-discrimination law that prohibits workplace discrimination against qualified individuals with a disability. ${ }^{6} \mathrm{~A}$ difficult substantive question was presented: Is the determination of whether one has a disability within the meaning of the ADA to be made with or without regard to mitigating measures?" Instinctively, either a "yes" or a "no" answer seems problematic. On the one hand, defining disability without regard to the corrective effects of medication or other devices, such as eyeglasses or hearing aids, could so enlarge the class of legally protected people as to trivialize the very real concerns that prompted the enactment of the ADA. On the other hand, if a corrected impairment is not considered disabling, the statute is likely to exclude a large number of people whose exclusion seems perverse. For example, an epileptic or diabetic whose condition is controlled through medication,

based on a permissible construction of the statute.

Id. at $842-43$.

The Chevron decision, touted as one that "promises to be a pillar in administrative law for many years to come," Cass R. Sunstein, Law and Administration After Chevron, 90 COLUM. L. REV. 2071, 2075 (1990), was important for its willingness to find implied delegations of interpretive authority. $I d$. at 2074-75. The Court premised this deferential review standard on the greater political accountability of administrative agencies. 467 U.S. at 865 . When policy choices are to be made, the Chevron Court determined that Congress would prefer those choices to be made by politically accountable agencies, rather than by politically unaccountable courts. See id.

But despite its rhetoric, there has been some question from the outset about the Court's commitment to Chevron. See Thomas W. Merrill, Judicial Deference to Executive Precedent, 101 YALE L.J. 969 (1992); Richard J. Pierce, Jr., The Supreme Court's New Hypertextualism: An Invitation to Cacophony and Incoherence in the Administrative State, 95 COLUM. L. REV. 749 (1995).

Academic writing praising and criticizing Chevron is legion. Prominent examples, in addition to the sources cited above, include Cynthia R. Farina, Statutory Interpretation and the Balance of Power in the Administrative State, 89 COLUM. L. REV. 452 (1989); Douglas W. Kmiec, Judicial Deference to Executive Agencies and the Decline of the Nondelegation Doctrine, 2 ADMIN. L.J. AM. U. 269 (1988); Richard J. Pierce, Jr., Chevron and Its Aftermath: Judicial Review of Agency Interpretations of Statutory Provisions, 41 VAND. L. REV. 301 (1988); The Honorable Antonin Scalia, Judicial Deference to Administrative Interpretations of Law, 1989 DUKE L.J. 511; Kenneth W. Starr, Judicial Review in the Post-Chevron Era, 3 Yale J. ON REG. 283 (1986); Eric M. Braun, Note, Coring the Seedless Grape: A Reinterpretation of Chevron U.S.A, Inc. v. NRDC, 87 COLUM. L. REV. 986 (1987).

5. Sutton v. United Air Lines, Inc., 527 U.S. 471 (1999). Two companion cases, Murphy v. United Parcel Serv., Inc., 527 U.S. 516 (1999) and Albertson's, Inc. v. Kirkingburg, 527 U.S. 535 (1999), presented the same issue to the Court. Because the Court chose Sutton as its vehicle for exploring the issue, this Article focuses on the Sutton case.

6. 42 U.S.C. $\S \S 12101-12213$ (1994).

7. In Sutton, twin sisters suffered from myopia that was fully correctable when they wore their glasses. Sutton, 527 U.S. at 475. In Murphy, Vaughn Murphy's high blood pressure was stabilized with medication. Murphy, 527 U.S. at 519. Mr. Kirkingburg's body had selfcorrected, to a degree, the effects of his monocular vision. Kirkingburg, 527 U.S. at 565-66. 
or perhaps an amputee whose prosthetic limb enables her to walk or even run, may not be substantially limited in performing major life activities because of the mitigating effects of the medication or prosthesis. If the impairment is then not considered disabling, an employer would be free to fire or not to hire the individual because she was an epileptic, a diabetic, or an amputee. Whatever else Congress had in mind when it passed the ADA, protecting individuals from such status discrimination would seem to have been firmly within the scope of the statute's prohibitions. ${ }^{8}$

The ADA is a broadly worded statute, ${ }^{9}$ and Congress recognized that its implementation would require administrative agencies to flesh out its terms. Consequently, Congress granted the EEOC substantive rulemaking authority to promulgate regulations for carrying out the ADA's employment provisions, ${ }^{10}$ an authority that Congress had withheld from the agency under Title VII of the Civil Rights Act of 1964. ${ }^{11}$ The EEOC complied with Congress's directions to have its ADA regulations in place one year before the statute took effect. ${ }^{12}$ The EEOC's regulations included an Interpretive Guidance that specifically addressed the issue of mitigating measures. ${ }^{13}$ The EEOC took the position that whether one has a disability should be assessed without regard to mitigating measures. ${ }^{14}$

A number of lower courts subsequently confronted this question, with some accepting the agency's position and others rejecting it. ${ }^{15}$ The

8. See S. REP. No. 101-116, at 23 (1989); H.R. REP. No. 101-485, pt. 3, at 28 (1990).

9. See Thomas H. Barnard, The Americans with Disabilities Act: Nightmare for Employers and Dream for Lawyers?, 64 ST. JOHN'S L. REV. 229, 239-41 (1990) (noting statute's many ambiguities); Stephen F. Befort and Holly Lindquist Thomas, The ADA in Turmoil: Judicial Dissonance, the Supreme Court's Response, and the Future of Disability Discrimination Law, 78 OR. L. REV. 27, 71 (1999) (same).

10. 42 U.S.C. $\$ 12116$.

11. Congress did not confer substantive rulemaking authority on the agency under Title VII; the EEOC possesses only procedural rulemaking authority under that statute. 42 U.S.C. $\S 2000 \mathrm{e}-12$ (1994). Whether a delegation of substantive rulemaking authority is a necessary predicate for a finding of an implied delegation of interpretive authority is an open question. See infra notes 75-81 for discussion of this point.

12. 29 C.F.R. pt. 1630 (1999).

13. 29 C.F.R. pt. 1630 , app. $\$ 1630.2(j)$ (1999). The Interpretive Guidance was subject to the same notice and comment rulemaking procedure as the regulations themselves.

14. "The determination of whether an individual is substantially limited in a major life activity must be made on a case by case basis, without regard to mitigating measures such as medicines, or assistive or prosthetic devices." $I d$.

15. Washington v. HCA Health Servs. of Tex., Inc., 152 F.3d 464 (5th Cir. 1998), vacated, 527 U.S. 1032 (1999) (mitigating measures generally need not be taken into account); Arnold v. United Parcel Serv., Inc., 136 F.3d 854 (1st Cir. 1998) (same); Sutton v. United Air Lines, Inc., 130 F.3d 893 (10th Cir. 1997), aff d, 527 U.S. 471 (1999) (mitigating measures to be taken into account); Matczak v. Frankford Candy and Chocolate Co., 136 F.3d 933 (3d Cir. 1997) (assess impairment in unmitigated state); Gilday v. Mecosta County, 124 F.3d 760 (6th Cir. 1997) (take mitigating measures into account in some cases); Doane v. City of Omaha, 115 F.3d 624 (8th Cir. 1997), cert. denied, 522 U.S. 1048 (1998) (assess impairment in 
question of deference to the EEOC's views became a focal point of discussion among the circuit courts. ${ }^{16}$ The central issue was how the Chevron doctrine should apply to the EEOC's Interpretive Guidance on mitigating measures.

In Chevron U.S.A., Inc. v. Natural Resources Defense Council, Inc. ${ }^{17}$ the Supreme Court held that agency interpretations of silent or ambiguous statutes are binding on courts if the interpretations are reasonable and if Congress has delegated interpretive power to the agency. ${ }^{18}$ Under Chevron, a reviewing court will first ask whether the statute itself answers the interpretive question being asked. If it does, then no deference to the agency is due, as Congress has made the policy choice itself and incorporated the chosen policy in the statute. ${ }^{19}$ If the court determines that the statute does not address the issue, however, and if Congress has delegated interpretive authority to the agency, the court, under Chevron, will defer to the agency's reading of the statute so long as that reading is a reasonable one, even if it is not the reading the court itself would have chosen. ${ }^{20}$

Increasingly, the Supreme Court has chosen to resolve interpretive questions at Step One of the Chevron analysis. It frequently has done so by using a textualist approach to statutory interpretation that finds in the statute itself an answer to the interpretive question posed. ${ }^{21}$

unmitigated state); Harris v. H \& W Contracting Co., 102 F.3d 516 (11th Cir. 1996) (same). For an overview of these cases, see Isaac S. Greaney, Note, The Practical Impossibility of Considering the Effect of Mitigating Measures Under the Americans with Disabilities Act of 1990, 26 FORDHAM URB. L.J. 1267 (1999).

16. Even courts that agreed with the agency's position disagreed on the amount of deference that was due the EEOC's Interpretive Guidance. Compare Harris, 102 F.3d at 521 (applying Chevron deference), with Washington, 152 F.3d at 469-70 (refusing to give Chevron deference to Interpretive Guidance). See Jonathan Bridges, Note, Mitigating Measures Under the Americans with Disabilities Act: Interpretation and Deference in the Judicial Process, 74 NOTRE DAME L. REV. 1061, 1065 (1999).

\section{467 U.S. 837 (1984).}

18. Chevron is based on an implied delegation theory; courts are to defer to agency interpretation of statutes because "Congress has told them to do so." Sunstein, supra note 4, at 2084 (emphasis removed). See also Adams Fruit Co. v. Barrett, 494 U.S. 638, 649 (1990) ("A precondition to deference under Chevron is a congressional delegation of administrative authority."). When has such a delegation of interpretive authority occurred? That is an open question. When Congress has conferred substantive rulemaking authority on the agency, it is widely acknowledged that such a delegation of interpretive authority has occurred. See Colin S. Diver, Statutory Interpretation in the Administrative State, 133 U. PA. L. REV. 549, 593-95 (1985); John F. Duffy, Administrative Common Law in Judicial Review, 77 TEX. L. REV. 113, 199 (1998); Sunstein, supra note 4, at 2093. Some, however, insist that the presence of statutory ambiguity or silence in an agency-administered statute is itself an implicit delegation of interpretive authority. The most prominent supporter of this view is Justice Scalia. See Scalia, supra note 4, at 516. This view, however, has been criticized. See, e.g., Duffy, supra, at 189-210.

19. See Chevron, 467 U.S. at $842-43$.

20. Id.

21. For a discussion and criticism of the "textualist" approach, see Bradford C. Mank, Textualism's Selective Canons of Statutory Construction: Reinvigorating Individual Liberties, 
Lower courts (and the academic literature) debated whether the "mitigating measures" question posed by the ADA could be resolved at Step One of Chevron. ${ }^{22}$ In Sutton $v$. United Air Lines, ${ }^{23}$ the Tenth Circuit asserted that it could, holding that the language of the ADA clearly states that disability determinations are to take into account the effects of any mitigating or corrective measures utilized by the individual. ${ }^{24}$ The Tenth Circuit rejected the EEOC's contrary view, published in the EEOC's Interpretive Guidance. ${ }^{25}$ After granting certiorari to hear Sutton $v$. United Air Lines, the Supreme Court, in an opinion by Justice O'Connor, affirmed the Tenth Circuit and held that an impairment must be assessed in its mitigated state. ${ }^{26}$

As a matter of substantive law, the Sutton Court's narrow interpretation of the definition of disability is troubling, particularly in the context of workplace discrimination. ${ }^{27}$ The employment provisions of the ADA, located in Title I, protect only those disabled persons who can perform the essential functions of their jobs. ${ }^{28}$ Often it is the miti-

Legislative Authority and Deference to Executive Agencies, 86 KY. L.J. 527 (1997-98); Pierce, supra note 4, at 752, 754-62.

22. See supra note 15; see also Ruth Colker, The Americans with Disabilities Act: $A$ Windfall for Defendants, 34 HARV. C.R.-C.L. L. REV. 99 (1999) (advocating deference to EEOC Guidance); Erica Worth Harris, Controlled Impairments Under the Americans with Disabilities Act: A Search for the Meaning of "Disability," 73 WASH. L. REV. 575 (1998) (finding language of the ADA unambiguously requires consideration of mitigating measures); Thais Hernandez, An Application of the Chevron Doctrine to the EEOC's Interpretation of the ADA: Why Mitigating Measures Must Be Considered When Evaluating A Disability, 7 U. MIAMI BUS. L. J. 309 (1999) (contending that an impairment should be assessed in its mitigated state); Bridges, supra note 16, at 1073 (arguing for resolution of the mitigating measures issue at Step One of Chevron); Isaac S. Greaney, Note, The Practical Impossibility of Considering the Effect of Mitigating Measures Under the Americans with Disabilities Act of 1990, 26 FORDHAM URB. L.J. 1267 (1999) (advocating following Guidance); Sheryl Rebecca Kamholz, Note, The Americans with Disabilities Act: Advocating Judicial Deference to the EEOC's Mitigating Measures Guidelines, 8 B.U. PUB. INT. L.J. 99 (1998) (urging courts to defer to guidelines at Chevron's Step Two); Michael J. Puma, Note, Respecting the Plain Language of the ADA: A Textualist Argument Rejecting the EEOC's Analysis of Controlled Disabilities, 67 GEO. WASH. L. REV. 123 (1998) (finding statutory language unambiguous); Recent Cases, 111 HARV. L. REV. 2438, 2456-61 (1998) (urging deference to EEOC Guidance on mitigating measures).

23. 130 F.3d 893 (10th Cir. 1997).

24. See id. at 902.

25. $1 d$.

26. 527 U.S. 471,487 (1999). The reasoning in Sutton was then applied in Murphy v. United Parcel Serv., Inc., 527 U.S. 516, 519 (1999) and Albertson's, Inc. v. Kirkingburg, 527 U.S. 555, 565 (1999).

27. Title I of the ADA provides that "[n]o covered entity shall discriminate against a qualified individual with a disability because of the disability of such individual in regard to job application procedures, the hiring, advancement, or discharge of employees, employee compensation, job training, and other terms, conditions, and privileges of employment." 42 U.S.C. $\$ 12112(\mathrm{a})$ (1994).

28. See 42 U.S.C. $\S 12111(8)$ (1994). A "qualified individual with a disability" is defined as "an individual with a disability who, with or without reasonable accommodation, can perform the essential functions of the employment position that such individual holds or de- 
gating measure that enables an individual to do her work. Under Sutton, mitigating measures that would otherwise have brought the individual within the ADA's Title I protections against employment discrimination will now often keep her outside the scope of the ADA altogether. ${ }^{29}$

At least as troubling, however, is the Court's refusal to defer to the EEOC's statutory interpretation. As EEOC Vice-Chair Paul Igasaki observed, in response to the Court's Sutton decision, "[W]hen the Supreme Court 'respectfully disagrees' with the EEOC, that has an impact." ${ }^{30}$ Not only is the EEOC's influence on the substantive law of employment discrimination reduced, but the agency's credibility is likewise compromised.

The Sutton Court's refusal to defer to the EEOC, however, raises questions that transcend both the EEOC's credibility and the substantive law of employment discrimination. Sutton was a case at the intersection of administrative and discrimination law, presenting a vehicle for exploring a number of unanswered questions about the Chevron doctrine. First, Sutton presented an opportunity for the Court to consider the role of administrative agencies in determining the scope of government programs for the disabled. The Court previously had recognized that determining legal protections for the disabled is a task for which the judiciary is not well-suited ${ }^{31}$ In Sutton, however, the Court ignored both the EEOC's and the Attorney General's opinions in determining the scope of ADA protections. Second, Sutton also presented an opportunity for the Court to explore whether deference on matters of employment discrimination, matters that involve some of this country's most deeply pressing social problems, are appropriate for Chevron analysis. Perhaps the Sutton result signifies the Court's reluctance to surrender interpretive authority to an administrative agency when confronting statutes aimed at implementing civil rights. Third, although the Court has been inconsistent in its application of

sires." Id.

29. See Sutton, 527 U.S. at 511 (Stevens, J., dissenting). As noted by Arlene Mayerson, an attorney for the Disability Rights Education and Defense Fund, "'ii]t doesn't make any sense' to consider ADA plaintiffs in their corrected state if employers rejected them because of their uncorrected conditions." Susan J. McGolrick, Supreme Court's Three ADA Decisions Disappoint Disability Rights Advocates, 68 U.S. L. Wk. 2035 (1999).

30. Lois Rose, Disabilities Discrimination: Attorneys from Many Sides React to Trio of Recent Supreme Court Decisions, 154 Daily Lab. Rep. (BNA), at C-3 (August 11, 1999). Presumably, Mr. Igasaki was talking about the negative impact that Sutton would have on the EEOC's credibility and status with the courts.

31. City of Cleburne v. Cleburne Living Center, 473 U.S. 432 (1985) (declining to apply heightened scrutiny to protect the mentally disabled). As the Cleburne Court stated, "How this large and diversified group [i.e. the mentally disabled] is to be treated under the law is a difficult and often technical matter, very much a task for legislators guided by qualified professionals and not by the perhaps ill-informed opinions of the judiciary." Id. at 442-43. 
Chevron, ${ }^{32}$ the interpretive methodology the Court used to resolve the Sutton case at Chevron's Step One reflects an intent to imprint the Court's own meaning on ambiguous statutory language. This judicial activism at Chevron's Step One is at odds with the deference to agency interpretation that the Chevron doctrine symbolizes. ${ }^{33}$

Taking apart the deference questions presented in Sutton and its companion cases allows exploration of the role that administrative agencies should play in developing solutions to some of this country's most intractable problems, while also highlighting various ambiguities in the Chevron doctrine itself: Part II discusses the various types of judicial deference to agency decisionmaking that a court might apply to administrative agencies. Part III examines the EEOC's statutory authority under Title VII, the ADEA, and the ADA, and the degree of deference that courts have historically accorded to EEOC interpretations of these statutes. Part IV examines the Court's holding in Sutton v. United Air Lines and reviews the options available to it for extending or withholding deference to the EEOC. Part V takes a step back from the case law and reflects on the appropriate roles of administrative agencies and courts in implementing civil rights in general and in setting policies for the disabled in particular. Part VI suggests how best to resolve the question of deference to the EEOC's regulations and Interpretive Guidance addressing Title I of the ADA, an issue the Court eventually will have to confront. Part VII concludes that jurisprudential and policy considerations strongly favor judicial deference to the EEOC's interpretations of the ADA.

\section{THE VARIOUS PERMUTATIONS OF DEFERENCE}

In discussing deference to agency interpretations of statutes, it is helpful first to define what deference means and why it matters. Deference to an agency's interpretations of law can come in three forms. Sometimes, deference means a reviewing court will consider the views of an agency and may find those views persuasive, but the court will retain for itself the ultimate interpretive power. ${ }^{34}$ The court essentially

32. See Pierce, supra note 4 , at $750,776-78$.

33. The Court's decision in Sutton has been harshly criticized as result-oriented jurisprudence. In an address to the ABA shortly after the decisions were handed down, Professor Harry F. Tepker, Jr., stated, "It is difficult to understand how the Court could conclude the Act need not protect amputees, persons suffering from myopia, high blood pressure, or other conditions merely because science has provided some amelioration for their undisputed physical shortcomings. ... The outcome ... is not textualism. It is judicial activism in service of judicial skepticism." Harry F. Tepker, Jr., Writing the Law of Work on Nero's Pillars: The 1998-99 Term of the U.S. Supreme Court, 15 LAB. LAW. 181, 196-97 (1999). For other works criticizing the substantive result in Sutton, see Lisa Eichhorn, Applying the ADA to Mitigating Measures Cases: A Choice of Statutory Evils, 31 ARIZ. ST. L.J. 1071 (1999); Luther Sutter, The Americans with Disabilities Act of 1990: A Road Now Too Narrow, 22 U. ARK. LITTLE ROCK L. REV. 161 (2000).

34. See General Elec. Co. v. Gilbert, 429 U.S. 125, 141-45 (1976) (finding EEOC's inter- 
treats the agency's opinion as it would the opinion of an expert witness. ${ }^{35}$ This form of deference is often described as Skidmore deference, in reference to the Supreme Court's decision in Skidmore $v$. Swift \& $\mathrm{Co}^{36}$ In Skidmore, the Court held that the interpretations of an agency, which lacked power to issue substantive regulations, could nonetheless have the "power to persuade, if lacking power to control." 37

Deference to an administrative agency under Chevron means something more. If a court is reviewing an agency's interpretation of its governing statute and the court concludes at Chevron's Step One that Congress has not spoken to the question presented, Chevron's Step Two requires the court to accept the agency's interpretation so long as it is reasonable, even if the court disagrees with the agency's interpretation. ${ }^{38}$ Chevron-styled deference has been described as "meaningful deference," as it mandates "administrative displacement of judicial judgment." 39 The decision has been labeled both "evolutionary and revolutionary" 40 because it finds in silent or ambiguous statutes a delegation of law-interpreting authority to agencies charged with the administration and enforcement of those statutes. ${ }^{41}$

pretation unpersuasive)

35. See Diver, supra note 18 , at 565; see also Robert A. Anthony, Which Agency Interpretations Should Bind Citizens and the Courts?, 7 YALE J. ON REG. 1, 13 (1990).

36. 323 U.S. 134 (1944). At issue before the Court in Skidmore was the appropriate weight to attach to "rulings, interpretations and opinions" of the Wage-Hour Administrator, who lacked power to issue substantive regulations under the Fair Labor Standards Act. Id. at 140.

37. Id. at 140. An agency's interpretation may persuade the Court, depending upon the "thoroughness evident in its consideration, the validity of its reasoning, its consistency with earlier and later pronouncements, and all [other] factors which give it power to persuade, if lacking power to control." Id.

38. This distinction has been described as follows:

As a matter of practical judicial psychology, it may often make little operational difference whether an interpretation is reviewed independently but given Skidmore consideration or is reviewed for reasonableness under Chevron Step 2. But the conceptual difference is large. An interpretation subject to the limited review of Chevron's Step 2 binds the court - and therefore is law - unless it can be found unreasonable. The agency thus makes law.

Anthony, supra note 35 , at 40 . For a fuller discussion of the distinction between the Skidmore and Chevron review standards, see 1 KENNETH C. DAVIS \& RICHARD J. PIERCE, JR., ADMINISTRATIVE LAW TREATISE 239-47 (3d ed. 1994). (1983).

39. Henry P. Monaghan, Marbury and the Administrative State, 83 COLUM. L. REV. 1, 5

40. Starr, supra note 4, at 284.

41. See Chevron U.S.A., Inc. v. Natural Res. Def. Council, Inc., 467 U.S. 837, 865-66 (1984). As recently noted by the Court, "Deference under Chevron to an agency's construction of a statute that it administers is premised on the theory that a statute's ambiguity constitutes an implicit delegation from Congress to the agency to fill in the statutory gaps." Food and Drug Admin. v. Brown \& Williamson Tobacco Corp., 529 U.S. 120, 159 (2000). Chevron's significance derives from its recognition of an implied delegation of interpretive authority. As noted by one scholar, "Chevron's importance lay in its adoption of a categori- 
In contrast to the Skidmore and Chevron brands of deference, Seminole Rock deference attributes the greatest weight to agency determinations. ${ }^{42}$ Seminole Rock deference means that an agency's interpretation of its own regulations are conclusive and binding on the courts, so long as the agency's interpretation is neither arbitrary nor capricious. ${ }^{43}$

Both the Skidmore and Seminole Rock forms of deference have been accepted components of administrative law since the 1940s. Neither form has proved particularly controversial. Skidmore deference does not displace the judicial authority to interpret ambiguous statutes independently, and Seminole Rock deference does not implicate statutory interpretation at all. Chevron, in contrast, has proved controversial from the outset, as it potentially serves as a "kind of Marbury, or counter-Marbury, for the administrative state." ${ }^{44}$ But the extent to which Chevron actually results in agencies, not courts, supplying statutory meaning ultimately depends on how the Court applies Chevron's first step. Disagreement exists within the Court on how courts should determine whether Congress expressed a clear intent on the interpretive question presented.

Under Step One of Chevron, a reviewing court, when confronting a question of statutory construction, will first ask whether the statute directly speaks to the precise question at issue..$^{45}$ If it does, the court gives effect to the statute's plain meaning, obviating any need to decide whether or not to defer to an administrative agency's interpretation. ${ }^{46}$ When Congress itself has resolved the policy choice before it, then no delegation of interpretive authority, to the courts or to the agency, has occurred.

cal presumption that silence or ambiguity in an agency-administered statute should be understood as an implicit delegation of authority to the agency." John F. Manning, Constitutional Structure and Judicial Deference to Agency Interpretations of Agency Rules, 96 Colum. L. Rev. 612, 623 (1996). Professor Manning credits Chevron with establishing a "new default presumption" for statutory interpretation. Id. at 625.

It is not clear, however, whether statutory silence or ambiguity alone is enough to support an inference of a delegation of interpretive authority or whether some independent indicia of an implied delegation, such as an express delegation of substantive rulemaking power, also is required. Michael Herz, Deference Running Riot: Separating Interpretation and Lawmaking Under Chevron, 6 ADMIN. L.J. AM. U. 187, 190-204 (1992). For extended discussion of this point, see Duffy, supra note 18, at 189-90, and White, supra note 2, at 76-87.

42. See Bowles v. Seminole Rock \& Sand Co., 325 U.S. 410 (1945). For a critique of the Seminole Rock doctrine, see Manning, supra note 41.

43. In deciding how a regulation should be construed, "the ultimate criterion is the administrative interpretation, which becomes of controlling weight unless it is plainly erroneous or inconsistent with the regulation." Seminole Rock, 325 U.S. at 414.

44. Sunstein, supra note 4, at 2075 (referring to Marbury v. Madison, 5 U.S. (1 Cranch) 137, 177 (1803)).

45. Chevron, 467 U.S. at 842.

46. Id. at $842-43$. 
This first step of Chevron has proved to be the all-important step. ${ }^{47}$ If a statute is "clear," no deference is due to agency interpretations. But how "clear" must a statute be for a case to be resolved at Chevron's Step One ${ }^{48}$ Three years after Chevron, the Court applied a Chevron analysis in INS v. Cardoza-Fonseca.$^{49}$ In an opinion by Chevron's author, Justice Stevens, the Cardoza-Fonseca Court engaged in an expansive search for statutory meaning at Step One. Justice Stevens examined both the "ordinary meaning" of the statutory language and employed "traditional tools of statutory construction," including legislative history, to determine whether Congress expressed a clear intent on the issue presented. ${ }^{50}$

Such an expansive approach to statutory interpretation at Chevron's first step gives courts considerable room to flesh out statutory meaning. Justice Scalia, an outspoken critic of judicial activism, criticized the Cardoza-Fonseca majority for subverting the deferential intent of Chevron by increasing the stringency of the Step One test. ${ }^{51}$ Ironically, however, application of Justice Scalia's own "textualist" approach to statutory interpretation, which eschews the use of legislative history and assumes that legislative texts contain a "plain meaning," increases the likelihood ${ }^{52}$ that the Court will resolve Chevron cases at Step One. ${ }^{53}$ As Justice Scalia has candidly explained, a judge who follows a textualist approach to statutory construction rarely will need to defer to an agency's construction of a statute, for such a judge more often than not will find the answer to the question being asked in

47. That such would be the case was recognized from the outset. Starr, supra note 4, at 298 (identifying Chevron's first step as "the primary battleground on which litigation over agency interpretations [will be] fought"). In an article published eight years after Chevron was decided, Professor Thomas Merrill identified the Court's expansive approach to Step One of Chevron, an approach that permitted the Court, notwithstanding the Chevron opinion, to declare statutory meaning. Merrill, supra note 4, at 990 . This is a trend that has escalated. See Pierce, supra note 4, at 750, 752 (noting that the Court rarely reaches Step Two of Chevron).

48. As Justice Scalia has noted:

Here, of course, is the chink in Chevron's armor - the ambiguity that prevents it from being an absolutely clear guide to future judicial decisions (though still a better one that what was supplanted). How clear is clear? It is here, if Chevron is not abandoned, that the future battles over acceptance of agency interpretations of law will be fought.

Scalia, supra note 4 , at 520-21.

49. 480 U.S. 421 (1987).

50. Id. at $432-49$.

51. Cardoza-Fonseca, 480 U.S. at $452-53$ (Scalia, J., dissenting).

52. Justice Stevens had acknowledged that even when the plain language of a statute appears to settle an interpretive question, legislative history should still be consulted to ensure that Congress in fact meant what it appears to have said. $I d$. at 432 n.12.

53. Mank, supra note 21 , at 527 (describing Scalia as having "led a revival of textualist statutory interpretation on the Court"). See also Pierce, supra note 4, at 779 (suggesting that Justice Scalia's ego renders him reluctant to find a statutory puzzle he cannot solve). 
the statute itself. ${ }^{54}$ Not surprisingly, the Supreme Court's activist approaches to Chevron's Step One have trickled down to the lower courts. ${ }^{55}$

At issue in the Sutton case was which form of deference - Skidmore, Seminole Rock, or Chevron - if any, was due the EEOC's Interpretive Guidance on mitigating measures. ${ }^{56}$ The Court deflected this issue ${ }^{57}$ by employing a textualist approach to find "plain meaning" and clear congressional intent in the ADA.

Does Sutton signal that the Supreme Court is becoming increasingly uncomfortable with Chevron deference and, as a result, has committed itself to resolving Chevron cases at Step One? Or is there something about the Americans with Disabilities Act, and the polarizing yet important policy questions it broadly addresses, that makes the Court particularly uneasy with the specific question of deference to the EEOC? Alternatively, was the particular interpretive issue in Sutton, or the format in which the agency's interpretation was issued, a reason for failing to defer to the agency's interpretation? Each of these questions is explored below.

\section{THE EEOC AND THE AMERICANS WITH DISABILITIES ACT}

A threshold issue, which the EEOC and Justice Department ignored in their brief to the Court, is whether the EEOC is an agency whose statutory interpretations are entitled to Chevron review. The EEOC simply assumed Chevron would apply. The Court, however, has been reluctant to apply Chevron review to the EEOC's interpretations of the statutes it administers, most notably Title VII. Thus, whether the EEOC is an agency that deserves Chevron deference is a question that merits examination.

\section{A. Chevron and the EEOC}

Why might the Court believe the EEOC is an agency whose views are worth less than those of other agencies charged with administering statutes? Asking this question forces a brief examination of why courts

54. Scalia, supra note 4, at 24; see also Mank, supra note 21 , at 575-76, 585-86 (noting textualists are less likely to defer to agency under Chevron).

55. See Martini v. Federal Nat. Mortgage Ass'n, 178 F.3d 1336 (D.C. Cir. 1999).

56. Compare Sutton v. United Air Lines, Inc, 527 U.S. 471 (1999), with Arnold v. United Parcel Serv., Inc., 136 F.3d 854, 864 (1st Cir. 1998) (extending only Skidmore deference to EEOC's Interpretive Guidance); Gilday v. Mecosta County, 124 F.3d 760, 763 n.2 (6th Cir. 1997) (debating whether Skidmore or Seminole Rock form of deference should apply to the EEOC's Interpretive Guidance on Mitigating Measures); Harris v. H \& W Contracting Co., 102 F.3d 516, 521 (11th Cir. 1996) (extending Chevron deference to the Interpretive Guidance).

57. "Although the parties dispute the persuasive force of these interpretive guidelines, we have no need in this case to decide what deference is due." Sutton, 527 U.S. at 480. 
should defer to an administrative agency's construction of a statute it administers, or, more specifically, why the Supreme Court has said that they should. It also requires an examination of how the EEOC has fared when measured against these reasons.

As the Supreme Court recently explained, "deference is justified because " $[t]$ he responsibilities for assessing the wisdom of such policy choices and resolving the struggle between competing views of the public interest are not judicial ones,' and because... the agency[] [has] greater familiarity with the ever-changing facts and circumstances surrounding the subjects regulated." 58 Importantly, the Court has recognized that the Chevron doctrine is based on an implied delegation theory; courts defer to an agency's construction of a silent or ambiguous statute because Congress has directed them to do so. ${ }^{59}$ That the Chevron doctrine, at bottom, is based on a congressional delegation of interpretive authority has been widely recognized, although often criticized. ${ }^{60}$

Of course, such congressional direction often does not exist in so many words, ${ }^{61}$ and the circumstances under which such an implied delegation may be found has been a source of controversy under Chevron. ${ }^{62}$ The Court's prior treatment of the question of deference to the EEOC under Title VII and the ADEA nicely illustrates the uncertainties surrounding this question.

58. Food and Drug Admin. v. Brown \& Williamson Tobacco Corp., 529 U.S. 120, 132 (2000) (quoting Chevron U.S.A., Inc. v. Natural Res. Def. Council, Inc., 467 U.S. 837, 866 (1984)).

59. "Deference under Chevron to an agency's construction of a statute that it administers is premised on the theory that a statute's ambiguity constitutes an implicit delegation from Congress to the agency to fill in the statutory gaps." Id. at 159. See also Adams Fruit Co. v. Barrett, 494 U.S. 638, 649 (1990). See Herz, supra note 41, at 199; Sunstein, supra note 4, at 2084. As explained by Professor Monaghan:

[A] court is not abdicating its constitutional duty to 'say what the law is' by deferring to agency interpretations of law: it is simply applying the law as 'made' by the authorized lawmaking entity. Indeed, it would be violating legislative supremacy by failing to defer to the interpretation of an agency to the extent that the agency had been delegated law-making authority.

Monaghan, supra note 39 , at 27-28.

60. See Anthony, supra note 35, at 4-6; Duffy, supra note 18, at 189-203; Kmiec, supra note 4, at 277-279; Merrill, supra note 4, at 979.

61. See Stephen Breyer, Judicial Review of Questions of Law and Policy, 38 ADMIN. L. REV. 363, 370 (1986); Scalia, supra note 4, at 517.

62. As noted by Professor Anthony, deciding whether interpretive authority has been delegated "may be the most vexing of the many uncertainties left by Chevron." Anthony, supra note 35 , at 32 . This uncertainty continues. See Duffy, supra note 18 , at 189 (describing two views of Chevron: one that would find an implied delegation of interpretive authority from statutory ambiguity using the "common law" reasoning of Chevron and another that would find a delegation only from the delegation of substantive rulemaking authority). 


\section{The Title VII Background}

Over the years, the amount of deference due to the EEOC has been in question. ${ }^{63}$ Most of the Court's experience with the EEOC has been in connection with Title VII of the Civil Rights Act of 1964, which prohibits discrimination in employment on the basis of race, sex, color, religion, and national origin. ${ }^{64}$ Importantly, Congress did not confer substantive rulemaking authority on the EEOC with respect to Title VII.

In the early years of Title VII's enforcement, the Court paid "great deference" to the EEOC's interpretation of Title VII. ${ }^{65}$ Even as late as 1988, in EEOC v. Commercial Office Products Co. ${ }^{66}$ the Court had deferred to an EEOC procedural regulation, even though the Court acknowledged the agency's interpretation may not have been the most natural one. ${ }^{67}$ In deferring to the agency, the Court stated, "it is axiomatic that the EEOC's interpretation of Title VII, for which it has primary enforcement responsibility, need not be the best one by grammatical or any other standards. Rather, the EEOC's interpretation of ambiguous language need only be reasonable to be entitled to deference." ${ }^{\circ 8}$ Although the Court did not cite Chevron, it plainly had applied Chevron's "meaningful deference" approach. ${ }^{69}$

But in 1991 in EEOC v. Arabian American Oil Co. (ARAMCO), ${ }^{70}$ the Court refused to defer to the EEOC's view, reflected in a series of informal documents, that Title VII may be applied extraterritorially. Although the Court found the statutory language ambiguous, it refused to defer to the EEOC, citing Skidmore. ${ }^{71}$ Justice Scalia disagreed with the Court's approach, insisting that the EEOC, despite its lack of

63. For a more extended discussion of the Supreme Court's approach to the EEOC's statutory interpretations, see White, supra note 2 , at $63,71-76$, and Moot, supra note 3 , at 222-31.

64. 42 U.S.C. \$2000e (1994).

65. Griggs v. Duke Power Co., 401 U.S. 424, 434 (1971). By 1976, however, the Court backed away from this approach. In General Electric $C o$. v. Gilbert, the Court rejected an interpretive guideline equating discrimination on the basis of pregnancy with sex discrimination. 429 U.S. 125 (1976). In dismissing the agency's views, the Court noted that the EEOC had not been given the authority to issue substantive legislative rules and thus its guidelines were entitled to "less weight" from the courts. Id. at 141 . The EEOC would receive only Skidmore deference, said the Court, which meant its regulations had only the power to persuade. Id. at 141-42 (citing Skidmore v. Swift \& Co., 323 U.S. 134 (1944)). See supra notes 34-37 and accompanying text for a description of Skidmore deference.

66. 486 U.S. 107 (1988).

67. Id. at 114-15.

68. Id. at 115 (citing Oscar Mayer \& Co. v. Evans, 441 U.S. 750, 761 (1979)).

69. See Arabian Am. Oil Co., 499 U.S. at 260 (1991) (Scalia, J., concurring) (recognizing that the Commercial Office Products Court had applied a Chevron analysis).

70. 499 U.S. 244 (1991).

71. Id. at $257-58$. 
substantive rulemaking authority, was entitled to the benefit of Chevron analysis. ${ }^{72}$ Justice Scalia complained that the juxtaposition of Commercial Office Products with the majority's approach in $A R A M C O$ left "the state of the law regarding deference to the EEOC ... unsettled,"73 and he called for application of Chevron analysis when reviewing the agency's statutory interpretations. ${ }^{74}$

Although the law remains unsettled on this point, there is an important distinction between the Commercial Office Products and ARAMCO cases. Commercial Office Products involved a procedural regulation issued by the EEOC, ${ }^{75}$ and Title VII expressly confers on the agency the authority to promulgate procedural regulations. ${ }^{76}$ The delegation of rulemaking powers is widely acknowledged to support an implied delegation of interpretive authority. ${ }^{77}$ Thus, it is possible to reconcile the results in the Title VII cases based on the rulemaking powers expressly conferred on or withheld from the agency by Congress. ${ }^{78}$ The EEOC was delegated authority to issue procedural rules under Title VII, ${ }^{79}$ while the power to issue substantive rules was not granted. ${ }^{80}$ Thus, under this view, Chevron deference to the EEOC's procedural rules would be appropriate, while Chevron deference to the agency's interpretations of the statute's substantive provisions would not. ${ }^{81}$

72. Id. at 259-60 (Scalia, J., concurring).

73. Id. at 260 .

74. Id. at 259-60. Justice Scalia's urging that a Chevron analysis should govern the EEOC's interpretations of Title VII at first glance may seem surprising. However, since Justice Scalia rarely encounters a statute from which he cannot tease a plain meaning, it is rare for him to be in the position of deferring to an administrative agency's construction of a statute it administers. See Mank, supra note 21, at 590. Thus, he can call for broad application of Chevron, knowing he rarely will find himself at Step Two of that analysis. Of course, Scalia himself recognizes this point. Scalia, supra note 4, at 521 .

75. EEOC v. Commercial Office Prods., 486 U.S. 107, 109-19 (1988).

76. 42 U.S.C. $\S 2000 \mathrm{e}-12$ (1994).

77. See DAVIS \& PIERCE, supra note 38, at 119-20; Sunstein, supra note 4, at 2092-93. Professor Duffy believes that a grant of substantive rulemaking authority reconciles Chevron with the Administrative Procedure Act's requirement of notice and comment. If an agency has substantive rulemaking authority, then Congress has delegated the agency the authority to issue interpretations of statutory provisions. Duffy, supra note 18, at 189-204.

78. See Duffy, supra note 18 , at 203-04; White, supra note 2 , at 93 . But see Martini v. Federal Nat'l Mortgage Ass'n, 178 F.3d 1336 (D.C. Cir. 1999) (finding clear meaning at Step One of Chevron but expressing doubt over whether Chevron review applies to EEOC procedural regulations).

79. See supra note 76 and accompanying text.

80. See EEOC v. Arabian Am. Oil Co., 499 U.S. 244, 257 (1991).

81. Two recent Title VII decisions further cloud the issue of the EEOC's entitlement to deference under that statute. In Walters v. Metropolitan Educ. Enter., 519 U.S. 202 (1997), Justice Scalia, writing for a unanimous court, appeared to retreat from his claim that the EEOC is deserving of Chevron deference under Title VII. Walters asked the Court to decide how to count employees in determining whether Title VII's jurisdictional standards have 
Whether the Court will defer to the EEOC's interpretations under Title VII may turn on whether a procedural or substantive question is at issue. ${ }^{82}$ If so, the Supreme Court may have become accustomed to

been met. Id. at 204. Although the Court agreed with the EEOC's position that persons should be counted on each day an "employment relationship" exists, id. at 206, it did so without reference to Chevron. Moreover, Scalia expressly noted that the EEOC "lacks rulemaking authority over the issue," $i d$. at 207, a suggestion that has been read as a backing away from his position in $A R A M C O$. See Duffy, supra note 18, at 204.

Walters, however, may also be read as a decision resolved at Step One of Chevron, a reading in keeping with Scalia's textualist approach to statutory interpretation. The Walters Court apparently found the statutory language clear and unambiguous, invoking various dictionaries in support of its view of the statute's ordinary meaning. Resolving the case at Step One of Chevron, as Scalia appeared to do, sidestepped any need to decide what level of deference the agency's interpretation of the statute was due. See id.

Robinson v. Shell Oil Co., 519 U.S. 337 (1997), decided the same Term as Walters, is more difficult. The question presented in Robinson was whether or not a former employee is protected by Title VII's anti-retaliation provisions. Id. at 339. Justice Thomas, writing for a unanimous Court, began by asking whether the statute had a plain and unambiguous meaning, which is the first step in a Chevron analysis. He found it did not; the statute's reference to "employees" was ambiguous. If the EEOC were deserving of Chevron deference, the question would then have been whether the agency's interpretation of the statute was a reasonable one. But the Court did not ask that question. It instead went on to independently interpret the statute, finding that former employees are indeed within the statute's reach. Id. at 345-46.

Does the Court's independent search for statutory meaning in Robinson mean the EEOC is not entitled to Chevron deference under Title VII? Not exactly. The EEOC's view of the statute had been presented only in an amicus brief, not in a formal format, such as a procedural rule or an interpretive guideline. While the Court quoted the agency's brief with approval, it may have been unwilling to extend Chevron deference to substantive interpretations of the statute put forward without benefit of rulemaking procedures. Thus, Robinson, like Walters, leaves unresolved what level of the deference the agency is due under Title VII. But see Donna P. Fenn, Note, Robinson v. Shell Oil Co.: Providing Former Employees with Protection From Retaliation, 15 HOFSTRA LAB. \& EMP. L.J. 539, 565 (1998) (Robinson illustrates the benefits of deference to the EEOC interpreting Title VII).

82. Many embrace the view that the Chevron analysis does not apply to the EEOC's interpretations of Title VII because the EEOC lacks substantive rulemaking authority. See DAVIS \& PIERCE, supra note 38, at 119-22, 235-36; Duffy, supra note 18, at 204; Sunstein, supra note 4, at 2093; Jamie A. Yavelberg, Comment, The Revival of Skidmore v. Swift: Judicial Deference to Agency Interpretation After EEOC v. ARAMCO, 42 DUKE L.J. 166, 19091 (1992). Others, most prominently Justice Scalia, view statutory ambiguity as a grant of interpretive authority to the administrative agency charged with administering the statute and thus would apply Chevron to the EEOC. Scalia, supra note 4, at 516; ARAMCO, 499 U.S. at 259-60 (Scalia, J., concurring).

My own view is more nuanced. I do agree with the prevailing view that a grant of substantive rulemaking powers to an agency constitutes a presumptive delegation of interpretive authority. But I do not agree that such a grant should be considered an absolute requisite for finding a delegation of interpretive authority. Rather, when substantive rulemaking authority does not exist, a reviewing court, without indulging any presumption in favor of the agency, should examine the particular legislation to decide whether an implied grant of interpretive authority is appropriate in the context of that statute. Viewing Title VII as a whole, I conclude that a delegation of interpretive authority to the EEOC should be found. White, supra note 2, at 79-87, 92-102. See also Diver, supra note 18, at 593-95. For other articles advocating an examination of statutory context in determining whether a delegation of statutory interpretive authority has been made, see Breyer, supra note 61, at 370-71; Kevin W. Saunders, Interpretative Rules with Legislative Effect: An Analysis and a Proposal for Public Participation, 1986 DUKE L.J. 346, 358-60; and Braun, supra note 4, at 994. I do not 
putting its own imprint on employment discrimination law under Title VII, looking to the agency's interpretations merely as useful input to be considered by the Court in its own independent interpretation of the statute. ${ }^{83}$

\section{Deference to the EEOC Under the ADEA}

The EEOC is also responsible for the administration and enforcement of the Age Discrimination in Employment Act. ${ }^{84}$ Importantly, however, Congress granted the EEOC both substantive and procedural rulemaking authority under that statute ${ }^{85}$ Thus, if a grant of substantive rulemaking authority is the necessary predicate for Chevron review, that predicate has been met under the ADEA.

In Public Employees Retirement System v. Betts in 1989, ${ }^{86}$ the EEOC claimed entitlement to Chevron deference and asked the Court to defer to its regulation interpreting the term "subterfuge" in the ADEA ${ }^{87}$ The Court refused to defer after finding the agency's interpretation at odds with the "plain language" of the statute. ${ }^{88}$ Betts thus appears to have been decided at Step One of Chevron, although the case is not absolutely clear on this point. The Court, importantly, did not dispute the applicability of Chevron review to the agency's ADEA interpretations.

On one other occasion, the EEOC has pressed a claim to Chevron deference under the ADEA. In Gregory v. Ashcroft ${ }^{89}$ the EEOC contended that appointed state court judges were covered by the ADEA, a point of view rejected by the Court. ${ }^{90}$ The agency's position in Ashcroft, however, had been articulated only in the course of litigation, rather than in an interpretive format following notice and comment. ${ }^{91}$

agree with Justice Scalia, however, that statutory ambiguity, standing alone, creates a presumption that interpretive authority has been delegated when an agency has not been delegated substantive rulemaking or adjudicatory powers. White, supra note 2, at 86-87.

83. See Colker, supra note 22, at 139-40; William N. Eskridge, Jr., Reneging on History? Playing the Court/Congress/President Civil Rights Game, 79 CAL. L. REV., 613, 664 (1991) (noting the Court "imposes its own preferences onto civil rights statutes").

84. 29 U.S.C. $\$ 626$ (1994).

85. 29 U.S.C. $\$ 628$ (1994).

86. 492 U.S. 158 (1989).

87. Id. at $170-72$.

88. Id. at 171.

89. 501 U.S. 452 (1991).

90. Id. at 488 .

91. See id. at 485 n.3 (White, J., concurring). For a further discussion of the format issue, see infra notes 297-301 and accompanying text. 
The Supreme Court decided Sutton against this background. The Court had become accustomed under both Title VII and the ADEA, but particularly under Title VII, to interpreting independently the statutes the EEOC administers. The EEOC's lack of authority to promulgate substantive regulations under Title VII, the statute with which the agency has been most closely identified, has fostered a perception that the EEOC is a weak agency. ${ }^{92}$ The agency's "never-never land status" under Title VII may well explain the Court's reluctance to recognize the EEOC as a major player in the interpretation of the ADA. ${ }^{94}$ However, the EEOC's claim to deference under Title I of the ADA stands on different, and stronger, footing. ${ }^{95}$

\section{Deference to the EEOC Under the ADA}

Congress enacted the ADA in 1990, when the Chevron doctrine was a well-recognized component of the administrative law landscape. Perhaps the most important employment discrimination statute enacted since the Civil Rights Act of 1964, the ADA provides protection in the public and private sectors from disability-based discrimination in a variety of settings, including public services provided by state and local government, public accommodations provided by private entities, and transportation. ${ }^{96}$ Most important for present purposes, Title I of the ADA prohibits discrimination in employment against a qualified individual with a disability. ${ }^{97}$

92. Colker, supra note 22, at 135-36, 39; see also Neal Devins, Political Will and the Unitary Executive: What Makes an Independent Agency Independent?, 15 CARDOzO L. REV. 273, 292 (1993) (EEOC has been viewed as a weak agency); White, supra note 2, at 56 (noting longstanding perception of agency's weakness as compared to other agencies).

93. Devins, supra note 92, at 296.

94. Even prior to Sutton, lower courts had paid little attention to the EEOC's regulations under the ADA. See Michael Higgins, No Sudden Impact: Courts Rejecting Mental Disability Claims Despite EEOC Guidelines Intended to Protect Mentally Ill, ABA J., Nov. 1997, at 24. (As of September 1997, no judge had cited guidelines in any opinion). As noted by one commentator, "The EEOC's ADA regulations have been a victim of the agency's historic second-class status; the courts continue to disregard its regulations and guidance, even when a very strong case can be made that Congress intended courts to give deference to those rules under the ADA." Colker, supra note 22, at 135-36, 139. See Wern, supra note 3, at 1578. $89-92$.

95. For an expanded discussion of the points set forth below, see White, supra note 2, at

96. See 42 U.S.C. $\$ \$ 12101-12213$ (1994).

97. See 42 U.S.C. $\$ \S 12111-12117$ (1994). There is some uncertainty over whether Title II of the ADA, which prohibits disability-based discrimination in public services, may be used to combat employment discrimination by entities covered by Title II. Compare Zimmerman v. Oregon Dept. of Justice, 170 F.3d 1169, 1183-84 (9th Cir. 1999), petition for cert. filed (No. 97-36101) (refusing employment claims under Title II) with Bledsoe v. Palm Beach County Soil and Water Conservation Dist., 133 F.3d 816, 818 (11th Cir. 1998), cert. denied, 525 U.S. 826 (1998) (allowing employment claims under Title II). 
The substantive provisions of Title I, as well as the definition of disability that applies to each of the ADA's titles, were derived primarily from experience under the Rehabilitation Act of 1973. ${ }^{98}$ That statute prohibited discrimination against the handicapped by the federal government, federal contractors, and those receiving federal financial assistance. The ADA comprehensively extended these prohibitions to private and public sector employers. The ADA not only borrows language from the Rehabilitation Act - and from case law and regulations interpreting and applying it - the ADA also expressly provides that it shall not "be construed to apply a lesser standard than the standards applied under ... the Rehabilitation Act of 1973 or the regulations issued by Federal agencies pursuant to [it.]"99 Thus, experience under the Rehabilitation Act was to inform interpretation of the ADA. ${ }^{100}$

The procedural provisions of Title I of the ADA, however, were imported from Title VII of the Civil Rights Act of 1964. Title I's enforcement scheme expressly incorporates the enforcement provisions of Title VII, thus making a charge with the EEOC a prerequisite to suit under Title I of the ADA. ${ }^{101}$

Importantly, Title I of the ADA contains the following provision: "Not later than 1 year after July 26, 1990, the Commission [EEOC] shall issue regulations in an accessible format to carry out this subchapter in accordance with [the Administrative Procedure Act]." 102 The EEOC fulfilled that mandate, issuing extensive regulations after notice and comment, ${ }^{103}$ accompanied by an appendix providing an Interpretive Guidance. ${ }^{104}$ A Technical Assistance Manual also was issued by the agency. ${ }^{105}$ Much of the agency's work product focused on the definition of a "disability" for purposes of Title I of the ADA. ${ }^{106}$

98. The Rehabilitation Act of 1973 was codified at 29 U.S.C. $§ 701$ (1994).

99. 42 U.S.C. $\$ 12201$ (a) (1994).

100. As noted by the Supreme Court, "The directive requires us to construe the ADA to grant at least as much protection as provided by the regulations implementing the Rehabilitation Act." Bragdon v. Abbott, 524 U.S. 624, 632 (1998).

101. See 42 U.S.C. $\$ 12117$ (1994).

102. 42 U.S.C. $\$ 12116$ (1994). Title I further provides a claim for a violation of the EEOC's regulations:

The powers, remedies, and procedures set forth in [Title VII] shall be the powers, remedies, and procedures this subchapter provides to the Commission, to the Attorney General, or to any person alleging discrimination on the basis of disability in violation of any provision of this chapter, or regulations promulgated under section 12116 of this title, concerning employment.

42 U.S.C. \$ 12117(a) (1994).

103. See 29 C.F.R. $\$ \$ 1630.1-.16$ (1999).

104. See 29 C.F.R. pt. 1630, app. (1999).

105. See EQUAL EMPlOYMENT OPPORTUNITY COMMISSION, A TECHNICAL assistance Manual on the Employment Provisions (Title I) of the Americans 
Against this background, the EEOC had a well-founded expectation that its statutory interpretations would receive Chevron deference. First, as mentioned above, Congress had granted the EEOC both substantive and procedural rulemaking authority under the ADA. ${ }^{107}$ If this is the sine qua non of a delegation of interpretive authority, ${ }^{108}$ the agency has it. Second, Congress conferred this authority on the agency in the post-Chevron era; Congress knows (or should know) that conferring rulemaking authority and/or enacting ambiguous statutes constitutes an implied (or explicit) delegation of interpretive authority. ${ }^{109}$ Third, Congress directed the agency to have its regulations in place one year before the ADA's effective date, ${ }^{110}$ evincing an understanding that the agency would give meaningful guidance to employers and individuals concerning their respective responsibilities and rights. ${ }^{111}$ Fourth, the statute provides a cause of action for violation of the EEOC's regulations, an acknowledgment of the agency's lawmaking powers. ${ }^{112}$ And finally, the statute requires charging parties to exhaust administrative procedures with the EEOC

WITH DISABILITIES ACT (1992).

106. 29 C.F.R. $\$ \S 1630.2($ h)-(l), 1630.3 (1999). The Regulations and Interpretive Guidance explicitly stated that they were issued for the purpose of implementing Title I of the ADA as it pertains "to the employment of qualified individuals with disabilities." 29 C.F.R. $\S 1630.1(\mathrm{a})$ (1999).

107. 42 U.S.C. $\$ 12116$ (1994) ("Not later than one year July 26, 1990, the Commission shall issue regulations in an accessible format to carry out this subchapter in accordance with subchapter II of chapter 5 of title 5.").

108. See supra notes 77-81 and accompanying text.

109. AT\&T Corp. v. Iowa Utils. Bd., 525 U.S. 366, 397 (1999) ("But Congress is well aware that the ambiguities it chooses to produce in a statute will be resolved by the implementing agency."); see also Manning, supra note 41, at 625 (Chevron "significantly revised the interpretive background against which Congress legislates."); Scalia, supra note 4, at 517 (stating that Congress now knows, when it legislates, that statutory ambiguities will be resolved by agencies, not courts).

110. 42 U.S.C. $\S 12116$.

111. As noted by the EEOC and Solicitor General in their amicus curiae brief to the Court in Murphy v. UPS:

Deference to administrative agency views is especially appropriate here, as the EEOC and the Department of Justice "played a pivotal role in 'setting [the statutory] machinery in motion.' " Ford Motor Credit Co. v. Milhollin, 444 U.S. 555, 566 (1980). When agencies promulgate their regulations virtually contemporaneously with a statute's enactment, utilizing the insights they derived from their participation in the legislative process, the rationale for granting deference is heightened. See National Muffler Dealers Ass'n v. United States, 440 U.S. 472, 477 (1979); United States v. Sheffield Bd. Of Comm'rs, 435 U.S. 110, 131 (1978); Zuber v. Allen, 396 U.S. 168, 192 (1969); United States v. Moore, 95 U.S. 760, 763 (1877).

Brief for the United States and the Equal Employment Opportunity Commission as Amicus Curiae Supporting Petitioner at 19-20, Murphy v. United Parcel Serv., Inc., 527 U.S. 516 (1999) (No. 97-1992). See also Colker, supra note 22, at 134 (arguing the regulations were promulgated under circumstances normally afforded the "highest judicial deference").

112. 42 U.S.C. $\$ 12117$ (a) (1994). 
before bringing suit; ${ }^{113}$ the EEOC is responsible for investigating and conciliating discrimination claims and also has the power to prosecute alleged violations. ${ }^{114}$ Statutory interpretation is necessary in performing these tasks, supporting the conclusion that Congress intended the agency to give meaning to the statute's gaps and ambiguities. ${ }^{115}$ Accordingly, the case for an implied delegation of interpretive authority to the EEOC under Title I of the ADA is compelling.

Scholars critical of the view that courts should defer to the EEOC note that Congress did not confer on the agency cease and desist powers, instead providing for de novo trials in all employment discrimination suits. ${ }^{16}$ Moreover, critics note that prosecutorial authority under Title I of the ADA, as is true for both Title VII and the ADEA, is shared with the Attorney General. While the EEOC may bring suit against private employers, it is the Attorney General who may sue governmental employers for employment discrimination. ${ }^{117}$

But these statutory provisions do not defeat the view that Congress made an implied delegation of interpretive authority to the EEOC. A grant of interpretive authority is not inconsistent with de novo litigation. An agency's interpretive regulation, issued following notice and comment procedures, is its view of what a statute means. Whether the statute, as interpreted by the agency, has been violated under the particular facts and circumstances of the case is the stuff of litigation. ${ }^{118}$ Thus, that parties have a right to a trial de novo under the ADA is compatible, not inconsistent, with a delegation of interpretive authority. ${ }^{119}$

113. Id.

114. Id.

115. See White, supra note 2 , at 96.

116. 42 U.S.C. $\$ 12117$ (a) (1994). The ADA simply incorporates Title VII's enforcement scheme, which requires charging parties to file charges with the agency but which permits de novo litigation in state or federal court after receiving a right to sue letter from the agency. This lack of enforcement authority has contributed to perceptions of the agency as weak. See Devins, supra note 92, at 298.

117. "Without cease-and-desist authority and with the Justice Department's concurrent authority to litigate employment discrimination actions, the EEOC was far from a prototypical independent regulatory agency." Devins, supra note 92 , at 298 . Additionally, as noted by Professor Devins, the Solicitor General represents the EEOC in proceedings before the Supreme Court and has "seem[ed] disinclined to allow the EEOC to advance competing arguments before the Supreme Court." Id. at 290.

118. See Duffy, supra note 18 , at 210 (recognizing Chevron's applicability even when a private cause of action exists); White, supra note 2 , at 92 ("This split enforcement scheme gives the agency the authority to resolve the broader policy questions left open under the statute while reserving to the courts the dispensing of individual justice.").

119. Wagner Seed Co. v. Bush, 946 F.2d 918, 920-22 (D.C. Cir. 1991) (recognizing that Congress may have wanted judiciary to determine liability while delegating to agency broader interpretive power). 
Nor is a sharing of prosecutorial power with the Attorney General inconsistent with Chevron deference to the EEOC's statutory interpretations. Indeed, such a suggestion reflects a misunderstanding of Chevron. Chevron does not compel deference to any agency's litigating position. ${ }^{120}$ That an agency has chosen to bring suit against an entity does not mean the agency wins so long as its position is not unreasonable. Rather, it is the agency's pre-existing statutory interpretations that are entitled to deference in the context of the litigation. An agency's decision to bring suit is not an interpretive act. Once suit is initiated, the court (or jury) will decide whether the statute, under the facts and circumstances of the case before it, has been violated, as is true in the context of private litigation.

Consequently, an analysis of the structure of the ADA, particularly its grant to the EEOC of substantive and procedural rulemaking authority under Title I, supports the EEOC's claim to a Chevron review standard. ${ }^{121}$ Even if one assumes the EEOC's lack of substantive rulemaking authority ${ }^{122}$ under Title VII suggests that Congress withheld interpretive authority from the EEOC under that statute, Congress's corresponding grant of substantive rulemaking authority to the EEOC under the ADA, along with other indicia, demonstrate that Congress intended the EEOC to exercise interpretive authority under the ADA.

\section{B. Defining the ADA's Protected Class}

Although Congress recognized the need for the EEOC to issue substantive regulations carrying out Title I, Congress itself promulgated a statutory definition of disability. In language drawn "almost verbatim" from the Rehabilitation Act, ${ }^{123}$ the ADA defines a disability as:

(A) a physical or mental impairment that substantially limits one or more of the major life activities of such individual;

(B) a record of such an impairment; or

(C) being regarded as having such an impairment. ${ }^{124}$

The statute thus provides three alternative routes to establishing the existence of a disability; an individual may be covered under one or more of these prongs.

120. Merrill, supra note 4 , at $987-88$.

121. See Sunstein, supra note 4, at 2086-87 (stating that Chevron review applies when a delegation of interpretive authority is the best reconstruction of congressional intent).

122. Id. at 2093 (arguing Chevron does not apply to agencies lacking substantive rulemaking authority); DAVIS \& PIERCE, supra note 38, at 235-36 (same).

123. Bragdon v. Abbott, 524 U.S. 624, 631 (1998).

124. 42 U.S.C. \& 12102(2) (1994). 
The ADA itself does not define what constitutes an "impairment" or a "major life activity," nor does it define what is meant by "substantially limits." The EEOC, however, devoted much attention and expertise to defining each of these terms, in both its regulations and in the Interpretive Guidance accompanying them. ${ }^{125}$

Protection under Title I of the ADA does not extend to all individuals with a disability. Instead, Title I's protections, by and large, are limited only to qualified individuals with a disability - that is, those disabled persons who can perform the essential duties of their jobs. ${ }^{126}$ Over one-half of the ADA cases to date have explored the question of whether a disability is present. ${ }^{127}$ Proving the existence of a disability is a threshold coverage issue under the ADA. Unlike Title VII, which extends its protections to all employees of a covered employer, the ADA protects from discrimination only those with a disability, as statutorily defined. ${ }^{128}$ Moreover, the protected class under Title I is even narrower, as the individual with a disability must be able to perform the essential functions of the job (s)he holds or desires before (s)he will fall within the protected class. ${ }^{129}$

125. See 29 C.F.R. $\$ \S 1630.2(\mathrm{~h})-(1), 1630.3$ (1999).

126. See 42 U.S.C. $\S 12112$ (a) (1994). A qualified individual with a disability is statutorily defined as one who can perform the essential functions of the job she holds or desires "with or without reasonable accommodation." See 42 U.S.C. $§ 12111(8)$ (1994). Statutory examples of reasonable accommodations include making facilities usable by the disabled and "job restructuring, part-time or modified work schedules, reassignment to a vacant position, acquisition or modification of equipment or devices, appropriate adjustment or modifications of examinations, training materials or policies, the provision of qualified readers or interpreters, and other similar accommodations for individuals with disabilities." 42 U.S.C. $\$$ 12111(9)(B) (1994). An accommodation that would pose an undue hardship on an employer is not a reasonable one. See 42 U.S.C. $\$ 12112$ (b)(5)(A) (1994 \& Supp. I 1995). The EEOC's regulations and Interpretive Guidance address in depth the agency's interpretation of "essential functions," "reasonable accommodation" and "undue hardship." 29 C.F.R. $\S$ 1630.2(n)-(p) (1999); 29 C.F.R.pt. 1630 app. \$ 1630.2(n)-(p) (1995).

Title I also prohibits discrimination against a qualified individual "because of the known disability of an individual with whom the qualified individual is known to have a relationship or association." 42 U.S.C. $\S 12112$ (b)(4) (1994). It is has been held, moreover, that the ADA's prohibitions against pre-employment medical inquiries and disclosure of medical information extend to nondisabled job applicants. See Cossette v. Minnesota Power \& Light, 188 F.3d 964, 969-70 (8th Cir. 1999).

127. Mary Crossley, The Disability Kaleidoscope, 74 NOTRE DAME L. REV. 621, 623 (1999).

128. See Interpretive Guidance on Title I of the Americans with Disabilities Act, 29 C.F.R. pt. 1630 app. (Background) (1999). See also Befort \& Thomas, supra note 9, at 69; Colker, supra note 22 , at $102-03$ (noting the disability definition as the key to ADA litigation).

129. See 42 U.S.C. $\S 12111(8)$ (1994). 


\section{Bragdon v. Abbott: Judicial Deference to Agency Interpretation Under the ADA?}

The Supreme Court first encountered the problem of determining what constitutes a disability under the ADA in the 1998 case of Bragdon v. Abbott. ${ }^{130}$ Bragdon was not an employment case; instead, it was brought under Title III of the ADA, which prohibits disability discrimination by a place of public accommodation. ${ }^{131}$ Nonetheless, it provides a useful background against which to examine Sutton. Both cases presented the Court with interpretive issues involving the meaning of "disability." Importantly, both cases also involved administrative guidance on the interpretive issues posed.

Sidney Abbott, who suffered from asymptomatic HIV infection, claimed her dentist, Randon Bragdon, had violated the ADA by refusing to fill her cavity in his office because she was HIV infected. ${ }^{132}$ Bragdon contended that asymptomatic HIV infection was not a disability within the meaning of the ADA, reasoning that Abbott's physical impairment did not substantially limit any of her major life activities. ${ }^{133}$ The Supreme Court disagreed. ${ }^{134}$

Justice Kennedy, writing for five justices, began by determining whether HIV infection was an "impairment" within the meaning of the ADA. In light of Congress's express directive in the ADA that protections under that statute were to be at least as stringent as those established by Rehabilitation Act regulations, ${ }^{135}$ the Court did so ${ }^{136}$ by analyzing HIV infection under regulations defining "impairment" issued by the Department of Health, Education and Welfare (HEW) under the Rehabilitation Act. ${ }^{137}$ Measuring Abbott's condition against those regulations, the Court had little difficulty concluding that HIV infection is an impairment. The Court went on to agree with Abbott's

130. 524 U.S. 624 (1998).

131. See 42 U.S.C. $\$ 12182(a)$ (1994 \& Supp. I 1995).

132. Bragdon, 524 U.S. at 629.

133. Id. at $639-42$.

134. Id. at 641 .

135. See 42 U.S.C. $\$ 12201$ (a) (1994).

136. See Bragdon, 524 U.S. at 632-33.

137. Those regulations define an impairment as:

(A) any physiological disorder or condition, cosmetic disfigurement, or anatomical loss affecting one or more of the following body systems: neurological; musculoskeletal; special sense organs; respiratory, including speech organs; cardiovascular; reproductive, digestive, genito-urinary; hemic and lymphatic; skin; and endocrine; or (B) any mental or psychological disorder, such as mental retardation, organic brain syndrome, emotional or mental illness, and specific learning disabilities.

45 C.F.R. $\$ 84.3(j)(2)(i)$ (1997). HEW's regulations were adopted verbatim by the Justice Department when enforcement of Section 504 of the Rehabilitation Act was transferred to the Attorney General. 28 C.F.R. $§ 41.31(b)(1)$ (1997). 
contention that reproduction is a major life activity, ${ }^{138}$ again looking to Rehabilitation Act regulations in determining what constitutes a "major life activity." 139

In deciding whether asymptomatic HIV infection substantially limits the major life activity of reproduction, however, the Court noted that the "Rehabilitation Act regulations provide no additional guidance." 140 The Court then proceeded to analyze that question independently. The Court concluded that Abbott's HIV status did substantially limit her ability to reproduce, even though reproduction was admittedly not physically hampered by the virus. ${ }^{141}$ Accordingly, because Abbott had a physical impairment that substantially limited her major life activity of reproduction, the Court held that she was an individual with a disability. ${ }^{142}$

Although the Court readily deferred to HEW's regulations in deciding that Abbott had an impairment and that reproduction was a major life activity, the Court was not willing to accept as controlling other agency determinations, issued under both the Rehabilitation Act and under the ADA, that persons with asymptomatic HIV were individuals with a disability. ${ }^{143}$ The Court acknowledged as a "comprehensive and significant administrative precedent" 144 an opinion by the Office of Legal Counsel of the Department of Justice, which concluded that HIV-infected persons were protected by Section 504 of the Rehabilitation Act. ${ }^{145}$ Yet the Court used the opinion as merely persuasive authority for the Court's own conclusion regarding disability status. The OLC's views served only to "confirm" the Court's finding, not to

138. See Bragdon, 524 U.S. at 637-39. The Court noted that other major life activities also may have been substantially limited by Abbott's infection. However, it limited its inquiry to reproduction because that was the ground on which the case had been decided below and on which certiorari had been granted. Id. at 638 .

139. 45 C.F.R. $\$ 84.3(j)(2)(i i)$ (1997). As the Court explained:

These regulations are contrary to petitioner's attempt to limit the meaning of the term "major" to public activities. The inclusion of activities such as caring for one's self and performing manual tasks belies the suggestion that a task must have a public or economic character in order to be a major life activity for purposes of the ADA. On the contrary, the Rehabilitation Act regulations support the inclusion of reproduction as a major life activity, since reproduction could not be regarded as any less important than working and learning.

Bragdon, 524 U.S. at 639.

140. Bragdon, 524 U.S. at 639.

141. Id. at 639-47.

142. The Court, however, did not hold that asymptomatic HIV infection is a per se disability, finding it unnecessary to reach that question. Rather, the Court noted that Abbott's HIV infection influenced her decision not to bear a child, thereby substantially limiting her in the major life activity of reproduction. Id. at 641-42.

143. See id. at $642-44$ (citing agency views).

144. Id. at 642 .

145. Application of Section 504 of the Rehabilitation Act to HIV-Infected Individuals, 12 Op. Off. Legal Counsel 209, 210 (1988). 
control it. ${ }^{146}$ Although noting that "[e]very agency to consider the issue under the Rehabilitation Act found statutory coverage for persons with asymptomatic HIV,"147 the Court declared,

Responsibility for administering the Rehabilitation Act was not delegated to a single agency, but we need not pause to inquire whether this causes us to withhold deference to agency interpretations under Chevron U.S.A., Inc., v. Natural Resources Defense Council, Inc., 467 U.S. 837, 844 (1984). It is enough to observe that the well-reasoned views of the agencies implementing a statute "constitute a body of experience and informed judgment to which courts and litigants may properly resort for guidance." 148

The Court thus appeared to acknowledge the agencies' views on the matter were deserving of some form of deference, but it was comfortable only with extending Skidmore deference absent further consideration. ${ }^{149}$

This distinction between deference to the Rehabilitation Act regulations and agency interpretations of the Rehabilitation Act presented in other formats makes sense when we remember that it is the ADA, not the Rehabilitation Act, the Court was construing in Bragdon v. Abbott. The Rehabilitation Act regulations were controlling on the Court only because Congress expressly stated the meaning of disability under the ADA was to be measured against those regulations. ${ }^{150}$ Absent such a command, agency views of a prior statute would merely assist the Court in independently determining a subsequent statute's meaning under the well-established canon of construction that "[w]hen administrative and judicial interpretations have settled the meaning of an existing statutory provision, repetition of the same language in a new statute indicates, as a general matter, the intent to incorporate its administrative and judicial interpretations as well." 151

The Court, however, also considered the opinions of the Department of Justice and the EEOC, two of the agencies responsible for interpreting and implementing the ADA itself. Congress conferred on the Justice Department authority to implement the public accommodations provisions of the ADA. ${ }^{152}$ The Justice Department's regulations listed asymptomatic HIV as an "impairment," 153 and its Techni-

146. Bragdon, 524 U.S. at 642.

147. Id.

148. Id. (quoting Skidmore v. Swift \& Co., 323 U.S. 134, 139-40 (1944)).

149. For a discussion of the distinction between Chevron and Skidmore deference, see supra notes 34-41 and accompanying text.

150. See supra notes $99-100$ and accompanying text; Colker, supra note 22, at 152.

151. Bragdon, 524 U.S. at 645 (citing Lorillard v. Pons, 434 U.S. 575, 580-81 (1978)).

152. 42 U.S.C. $\S 12186($ b) (1994).

153. 28 C.F.R. $\$ 36.104(1)$ (iii) (1999). 
cal Assistance Manual concludes that persons with asymptomatic HIV infection do fall within the statutory definition of "disability." $154 \mathrm{Al}$ though the Court noted those interpretations, it did not accord Chevron deference to them. ${ }^{155}$ Moreover, the Court observed that its conclusion that Abbott was protected by the ADA was

further reinforced by the administrative guidance issued by the Justice Department to implement the public accommodation provisions of Title III of the ADA. As the agency directed by Congress to issue implementing regulations, to render technical assistance explaining the responsibilities of covered individuals and institutions, and to enforce Title III in court, the Department's views are entitled to deference. ${ }^{156}$

The Court also stated it drew "guidance from the views of the agencies authorized to administer other sections of the ADA," 157 including the EEOC's Interpretive Manual. ${ }^{158}$ The Court found these views "consistent with our holding that HIV infection, even in the socalled asymptomatic phase, is an impairment which substantially limits the major life activity of reproduction." 159

Some viewed the Court's decision in Bragdon v. Abbott as a sign that the Court was prepared to give agencies the lead in establishing the ADA's reach. ${ }^{160}$ In fact, however, the opinion is equivocal. First, while the Court's interpretations of Title III of the ADA tracked HEW's regulations, the Court was not willing to say that reasonable agency interpretations of those regulations were entitled to Chevron deference. ${ }^{161}$ Second, although the Court cited Chevron after remarking that the Justice Department's views of Title III were entitled to deference, the Court did not appear to engage in a Chevron analysis. Instead, it independently interpreted the statute and the HEW regula-

154. Civil Rights Div., U.S. Dep'T OF Justice, The AMERICANS With Disabilities ACT: TITLE III TECHNICAL AssistanCE MaNUAL 9 (1993).

155. Bragdon, 524 U.S. at 646.

156. Id. (citations omitted).

157. Id. at 647.

158. "Most categorical of all is EEOC's conclusion that 'an individual who has HIV infection (including asymptomatic HIV infection) is an individual with a disability.' In the EEOC's view, 'impairments ... such as HIV infection, are inherently substantially limiting.' " Id. (quoting EEOC Interpretive Manual $\S 902.4$ (c)(1), p. 902-21; 29 C.F.R. pt. 1630, app., at $350(1997))$.

159. Bragdon, 524 U.S. at 647.

160. See Befort \& Thomas, supra note 9, at 94-95 (explaining how Bragdon pointed toward deference); Colker, supra note 22, at 152; Greaney, supra note 22, at 1288-89. As Professor Colker asserts, "[Bragdon] explicitly held that the current ADA regulations 'are entitled to deference' under Chevron." Colker, supra note 22, at 152. The EEOC and the Justice Department shared this view. See Brief for the United States and the Equal Employment Opportunity Commission as Amicus Curiae Supporting Petitioner at 18-19, Murphy v. United Parcel Serv., Inc., 527 U.S. 516 (1999) (No. 97-1992) (Bragdon accorded "Chevron deference to, inter alia, administrative guidance interpreting the ADA").

161. Bragdon, 524 U.S. at 642. 
tions, using the Justice Department's views to "reinforce" its position. ${ }^{162} \mathrm{Had}$ a Chevron analysis been employed, the Court would have asked whether the statute spoke directly to the precise question at issue, and if not, would have asked whether the Justice Department's view was deserving of deference under Chevron's Step Two. ${ }^{163}$

The following Term, the Court created even more uncertainty over what form of deference, if any, applies to agency interpretations of the ADA. This time, the statute at issue was not Title III of the ADA, but Title I, and the agency at issue was not the Justice Department, but the EEOC.

\section{Sutton v. United Air Lines and the "Mitigating Measures" Puzzle: No Deference Extended}

In 1999, the Court again confronted the meaning of "disability" under the ADA. Three cases confronted a common issue: in determining whether an impairment substantially limits major life activities, should the court take into account mitigating measures, such as medication or auxiliary aids. ${ }^{164}$ Of the three cases, Sutton v. United Air Lines $^{165}$ is the most important because it served as the Court's primary vehicle for exploring this issue. ${ }^{166}$

Karen Sutton and Kimberly Hinton were twin sisters who sought employment as commercial airline pilots with United Air Lines. Each suffered from severe myopia of, at best, 20/200 uncorrected vision. Without eyeglasses they were legally blind. With glasses, however, they had, at worst, 20/20 vision. ${ }^{167}$ United rejected their applications because neither twin could meet United's requirement that its pilots

162. Id.; see also Duffy, supra note 18 , at 210 n.497.

163. As Professor Duffy correctly notes, the Court quoted and cited Chevron,

Yet the structure of the Court's analysis was entirely inconsistent with the framework established in Chevron: Rather than first deciding whether the statute was ambiguous and, if it was, then deferring to reasonable agency regulations, the Court interpreted the statute on its own, holding that "HIV infection [is] a disability under ... the definitional section of the statute." The Department of Justice's regulations were consulted only to "reinforce" the Court's own conclusion on the statute's proper interpretation.

Duffy, supra note 18, at $210 \mathrm{n} .497$ (citations omitted).

164. See Sutton v. United Air Lines, Inc., 527 U.S. 471 (1999); Murphy v. United Parcel Serv., Inc., 527 U.S. 516 (1999); Albertson's, Inc. v. Kirkingburg, 527 U.S. 535 (1999).

165. 527 U.S. 471 (1999).

166. See Murphy, 527 U.S. at 518 ("In light of our decision in Sutton v. United Airlines, Inc., we conclude that the Court of Appeals' resolution of both issues was correct.") (citation omitted); Kirkingburg, 527 U.S. at 565 ("We have just held, however, in Sutton v. United Airlines, Inc., that mitigating measures must be taken into account in judging whether an individual possesses a disability.") (citation omitted).

167. Sutton, 527 U.S. at 475. 
have 20/100 uncorrected vision. ${ }^{168}$ The sisters sued, claiming United's failure to hire them violated the ADA.

The Supreme Court agreed with the Tenth Circuit that the two women were not within the ADA's protected class. ${ }^{169}$ It did so after first concluding that the EEOC's view "that persons are to be evaluated in their hypothetical uncorrected state - is an impermissible interpretation of the ADA."170

The Court reached this result based on a textualist reading of the ADA as a whole, ${ }^{171}$ a reading made without consideration of extensive legislative history strongly supporting the EEOC's position. ${ }^{172}$ The Court instead looked to three provisions of the ADA. It first focused on the phrase "substantially limits," 173 a phrase in the "present indicative verb form." 174 That verb form, said the Court, requires that a person be "presently ... substantially limited." "175 "To be sure," said the Court, "a person whose physical or mental impairment is corrected by mitigating measures still has an impairment, but if the impairment is corrected it does not 'substantially limi[t]' a major life activity."176

168. Id. at 476.

169. Id. at 477 .

170. Id. at 482 .

171. "Looking at the Act as a whole, it is apparent that if a person is taking measures to correct for, or mitigate, a physical or mental impairment, the effects of those measures both positive and negative - must be taken into account when judging whether that person is 'substantially limited' in a major life activity and thus 'disabled' under the Act." Id.

172. "Because we decide that, by its terms, the ADA cannot be read [to preclude consideration of mitigating measures] we have no reason to consider the ADA's legislative history." Id. The legislative history weighing against the Court's position, however, was considerable. The Senate Report on the bill asserts that "whether a person has a disability should be assessed without regard to the availability of mitigating measures, such as reasonable accommodations or auxiliary aids." S. REP. NO. 101-116, at 23 (1989). House Committees expressed similar understandings. The Report of the House Committee on the Judiciary states, "The impairment should be assessed without considering whether mitigating measures, such as auxiliary aids or reasonable accommodations, would result in a less-than-substantial limitation." H.R. REP. NO. 101-485, pt. 3, at 28 (1990). The Report of the House Committee on Education and Labor provides that "[w]hether a person has a disability should be assessed without regard to the availability of mitigating measures, such as reasonable accommodations or auxiliary aids." H.R. REP. NO. 101-141, pt. 2, at 52 (1990). Justice Stevens' dissenting opinion quoted and relied upon these materials. See Sutton, 527 U.S. at 499-501.

173. Sutton, 527 U.S. at 482 . Recall that the ADA defines a disability primarily as "a physical or mental impairment that substantially limits one or more . . major life activities." 42 U.S.C. $\$ 12102(2)$ (A) (1994). That the sisters had an impairment was not questioned by the Court or the parties. Sutton, 527 U.S. at 490 . Rather, the question was whether that impairment substantially limited any major life activity.

174. Sutton, 527 U.S. at 482 ("Because the phrase 'substantially limits' appears in the Act in the present indicative verb form, we think the language is properly read as requiring that a person be presently - not potentially or hypothetically - substantially limited in order to demonstrate a disability.").

175. $I d$.

176. Id. at 483 . 
Second, the Court said statutory references to an "individual" required an individualized inquiry on disability status. ${ }^{177}$ The EEOC's approach "runs directly counter to the individualized inquiry mandated by the ADA,"178 as it would assess how people generally would be affected by an uncorrected impairment, a hypothetical inquiry at odds with the statute's focus on the impairment's actual effect on the individual in question. ${ }^{179}$

"[F]inally and critically," the Court looked to the findings enacted as part of the ADA, that "some $43,000,000$ Americans have one or more physical or mental disabilities." 180 The Court found this number, the source of which admittedly was unclear, dispositive. ${ }^{181}$

Had Congress intended to include all persons with corrected physical limitations among those covered by the Act, it undoubtedly would have cited a much higher number of disabled persons in the findings. That it did not is evidence that the ADA's coverage is restricted to only those whose impairments are not mitigated by corrective measures. ${ }^{182}$

Because the sisters, when wearing corrective lenses, could see perfectly, their impairment did not substantially limit any major life activity.

177. $I d$.

178. Id. at $483-84$.

179. The Court used the example of diabetes to illustrate what it viewed as a flaw in the guidelines. Under the EEOC's view,

courts would almost certainly find all diabetics to be disabled, because if they failed to monitor their blood sugar levels and administer insulin, they would almost certainly be substantially limited in one or more major life activities. A diabetic whose illness does not impair his or her daily activities would therefore be considered disabled simply because he or she has diabetes.

Id. at 483. Ironically, the Report of the House Committee on Education and Labor cited persons with diabetes as those who would be covered by the disability definition, even if the effects of their disease were controlled by their medication. H.R. REP. NO. 101-485, pt. 2, at 52 (1990). See also Sutton, 527 U.S. at 500-501 (Stevens, J., dissenting).

180. Sutton, 527 U.S. at 484 (quoting 42 U.S.C. § 12101(a)(1) (1994)).

181. Id. That the "exact source of the 43 million figure is not clear," as the Court confessed, is an understatement. No source identified by the Court corresponded to the 43 million figure. Without any support from the text or legislative history, however, the Court supposed that a 1988 report from the National Council on Disability - which was entitled "On the Threshold of Independence" and which identified 37.3 million people suffering from functional limitations when using mitigating measures - was significant to Congress's use of the figure of 43 million. The Court supposed that the 43 million "probably can be explained" by Congress's attempt to adjust the National Council's figure to include institutionalized persons excluded from its report. The Court also noted that reports on persons with "a health condition" cited substantially greater numbers. Id. at 485-86.

182. Id. at 487 . In her concurring opinion, Justice Ginsburg relied heavily on the 43 million figure. As she noted, "the inclusion of correctable disabilities within the ADA's domain would extend the Act's coverage to far more than 43 million people." Id. at 494 . Moreover, the findings described individuals with a disability as a "discrete and insular minority," which she viewed as inconsistent with coverage of "the large numbers of diverse individuals with corrected disabilities." Id. 
The Court also rejected the twins' argument that United regarded their impairment as substantially limiting the major life activity of working. ${ }^{183}$ EEOC regulations list "working" as a major life activity, ${ }^{184}$ and the parties accepted that view. ${ }^{185}$ Importantly, however, the Sutton Court not only questioned the EEOC's authority to promulgate the regulation but hinted strongly that it may not be prepared to view "working" as a major life activity ${ }^{186}$ thereby raising additional questions about the validity of the EEOC's regulations. The Court found it unnecessary to resolve this issue, however, as the regulations further provide that an individual is substantially limited in the major life activity of working only if the impairment restricts the individual from performing work in a broad class or range of jobs. ${ }^{187}$ Because United regarded the sisters as unable to perform only the job of global airline pilot, it did not regard them as unable to perform work in a broad class of jobs. ${ }^{188}$ Thus, because their impairment, in its mitigated state, neither substantially limited their ability to perform any major life activity, nor did their employer regard them as having any such impairment, Kimberly Sutton and Karen Hinton had no claim under the ADA. ${ }^{189}$

183. Id. at 490 . The Court stated:

There are two apparent ways in which individuals may fall within this statutory definition: (1) a covered entity mistakenly believes that a person has a physical impairment that substantially limits one or more major life activities, or (2) a covered entity mistakenly believes that an actual, nonlimiting impairment substantially limits one or more major life activities. In both cases, it is necessary that a covered entity entertain misperceptions about the individual. ..."

Id. at 489. The Court found that United did not regard the twins as substantially limited. Id. at $490-91$.

184. 29 C.F.R. $\S 1630.2(\mathrm{I})(1999)$.

185. Sutton, 527 U.S. at 492 ("Because the parties accept that the term 'major life activities' includes working, we do not determine the validity of the cited regulations.").

186. Id. (citing Transcript of Oral Arg. at 15, School Board of Nassau Co. v. Arline, 480 U.S. 273 (1986) (No. 85-1277)). This reservation on the Court's part appears inconsistent with Congress's stipulation that the ADA standards be no less protective than regulations adopted under the Rehabilitation Act. 42 U.S.C. $\$ 12201$ (a) (1994). Those regulations include working as a major life activity. 28 C.F.R. $\S 41.31(\mathrm{~b})(2)(1999) ; 45$ C.F.R. $\S$ 84.3(j)(2)(ii) (1999).

$$
\text { 187. } 29 \text { C.F.R. \& 1630.2(j)(3)(i) (1999). }
$$

188. Sutton, 527 U.S. at $493^{-}$. As the Court explained:

Even under the EEOC's Interpretive Guidance, to which petitioners ask us to defer, "an individual who cannot be a commercial airline pilot because of a minor vision impairment, but who can be a commercial airline co-pilot or a pilot for a courier service, would not be substantially limited in the major life activity of working."

Id. (quoting 29 C.F.R. pt. 1630, app. $\$ 1630.2$ ).

189. Having resolved the interpretive issue in Sutton, the Court then proceeded to apply that interpretation in the Murphy and Kirkingburg cases. Because Vaughn Murphy's high blood pressure, when medicated, did not substantially limit his ability to perform any major life activity, he had no disability under prong one. Murphy v. United Parcel Serv., Inc., 527 U.S. 516, 521 (1999). And because his employer did not regard him as unable to perform 


\section{THE SUTTON COURT'S APPLICATION OF CHEVRON}

Sutton was a stunning defeat for the EEOC. The agency, backed by the Justice Department, had aggressively sought deference to its position on the mitigating measures issue ${ }^{190}$ The EEOC, the independent agency with primary responsibility for civil rights enforcement, together with the Executive Branch, agreed on how best to resolve this difficult issue. Yet the Court summarily dismissed the EEOC's approach.

According to the EEOC, the statute was silent or ambiguous on the question of whether "the inquiry into substantial limitation of a major life activity is to be undertaken with or without taking into account mitigating measures." ${ }^{191}$ Thus, citing Chevron, the EEOC contended that the only question was whether its position was based on a permissible construction of the statute. And the agency insisted it was. Moreover, the EEOC asserted that deference was "especially appropriate here," given its "pivotal role 'in setting [the statutory] machinery in motion." "192 As the agency stated, "When agencies promulgate their regulations virtually contemporaneously with a statute's enactment, utilizing the insights they derived from their participation in the legislative process, the rationale for granting deference is heightened." ${ }^{193}$ And the EEOC insisted that, because its Interpretive Guidance interpreted its own regulations, the Guidance was entitled to the strongest form of judicial deference. ${ }^{194}$

Deference to the EEOC in Sutton would have given the agency the credibility and respect it has lacked for much of its existence. ${ }^{195}$ And it

mechanics' jobs generally, but only those that required driving a commercial motor vehicle, it did not regard him as having an impairment that substantially limited the major life activity of working, with the Court assuming arguendo the validity of the EEOC regulations. Id. at 522-23. In Albertson's Inc. v. Kirkingburg, 527 U.S. 555 (1999), the Court applied Sutton to ameliorative measures by which the body compensates for its own impairments, holding that those must be taken into account in determining whether a disability is present. Id. at 565-66. However, the Court found that even if Kirkingburg had a disability, he was not a qualified individual with a disability because he could not meet federal visual acuity standards. $I d$. at 567-76.

190. The EEOC has not always enjoyed the support of the Justice Department in its interpretation of the statutes it administers. See Devins, supra note 92, at 289-98. But in Sutton, the Justice Department agreed with the agency that the EEOC's interpretation was entitled to deference from the Court.

191. Brief for the United States and the Equal Employment Opportunity Commission as Amicus Curiae Supporting Petitioner at 9, Murphy v. United Parcel Serv., Inc., 527 U.S. 516 (1999) (No. 97-1992)No. 97-1992). The agency's amicus brief was invited by the Court. Id. at 1 .

192. Id. at 19 (quoting Ford Motor Credit Co. v. Milhollin, 444 U.S. 555, 565 (1980)).

193. Id. at 20.

194. Id. at 18-19.

195. See MiCHAEL I. SOVERN, LEGAL RESTRAINTS ON RACIAL DISCRIMINATION IN EMPLOYMENT 205 (1966) (describing the EEOC's weakness at its earliest stages). More recently, the EEOC has been described as the Justice Department's "whipping boy" and as an 
would have endorsed the independent agency's responsibility to define the parameters of the civil rights statute, as applied in the workplace. When a statute is laden with ambiguity, as the ADA is, ${ }^{196}$ recognizing the agency's leading role in its interpretation would have had significant consequences for development of employment discrimination policy and for the enforcement process. ${ }^{197}$

But are the EEOC's interpretations of the ADA ever entitled to Chevron review? This question is perhaps the most provocative issue left unresolved in Sutton. Its resolution requires not only an analysis of the Sutton reasoning but exploration of the question the Sutton Court pointedly did not resolve: what deference, if any, is owed the EEOC's regulations and interpretive guidances issued under the ADA?

It frankly is not clear whether the Sutton Court performed a Chevron analysis. The decision could be read in one of three ways: (1) Because Congress did not give any agency authority to issue regulations implementing the term "disability," the Chevron doctrine was inapplicable, leaving the Court to perform an independent analysis of the statute ${ }^{198}$ (2) assuming Chevron applies, the interpretive question may be resolved at Step One of Chevron, as the language of the statute itself answers the question being asked, ${ }^{199}$ or (3) assuming Chevron applies and the statutory meaning is uncertain, the agency's interpretation was rejected as an unreasonable reading of the statute. ${ }^{200}$.

On balance, the most defensible reading of the Sutton opinion is the second one, i.e. that the interpretive issue was resolved by the Court at Chevron's Step One. The Sutton Court was careful not to resolve the question of Chevron's applicability, ${ }^{201}$ thus making the first

agency long viewed as "weak." Devins, supra note 92, at 289, 292.

196. See Befort \& Thomas, supra note 9, at 71 ("The statute bans disability discrimination in a broad, sweeping outline, but leaves the details to the EEOC and the courts."); Nancy Lee Jones, Overview and Essential Requirements of the Americans with Disabilities Act, 64 TEMP. L. REV. 471, 489-90 (1991).

197. See White, supra note 2 , at 57 . As has been noted:

In essence, Congress, in enacting the ADA, announced its opposition to disability discrimination, but provided only minimal guidance in describing the type of conduct to which it was opposed. The end result is a large delegation of authority to the EEOC and the courts, and a significant contributing factor to the current divergence of judicial opinion.

Befort \& Thomas, supra note 9, at 72.

198. Sutton v. United Air Lines, Inc., 527 U.S. 471, 479 (1999) ("No agency, however, has been given authority to issue regulations implementing the generally applicable provisions of the ADA....").

199. Id. at 482. ("Looking at the Act as a whole, it is apparent that [mitigating measures] ... must be taken into account when judging whether [an individual] is 'substantially limited' in a major life activity and thus 'disabled' under the Act.").

200. Id. ("We conclude that respondent is correct that the approach adopted by the agency . . is an impermissible interpretation of the ADA.").

201. "Although the parties dispute the persuasive force of these interpretive guidelines, we have no need in this case to decide what deference is due." Id. at 480 . 
reading problematic. Although the Court noted that no agency had been delegated authority to promulgate regulations implementing the ADA's general provisions, in which the definition of "disability" is located, it did not hold Chevron inapplicable. Nor does the Court's opinion acknowledge ambiguity in the statute, making the third reading a difficult one to support. ${ }^{202}$ Instead, the Court appears to assume that Chevron's analysis does apply and to find an answer to the mitigating measures puzzle in the words and structure of the statute itself, leaving for another day the question of what deference, if any, is due the EEOC when interpreting the ADA. ${ }^{203}$

Sutton is a particularly dramatic example of a textualist approach to Step One of the Chevron two-step. None of the statutory provisions relied upon by the Court in finding congressional intent was dispositive of the question presented. ${ }^{204}$

First, the Sutton majority argued that the present indicative verb form of the ADA's criteria for "disability" implies that the statute covers only those who are "presently" disabled. But this argument begs the question whether mitigating measures are or are not to be considered in making the determination. ${ }^{205}$ In other words, were Ms. Sutton and Ms. Hinton "presently" disabled when their glasses were on or when their glasses were off?

Second, an individualized assessment of the sisters' impairment and its effect on their major life activities required no hypothetical inquiry or generalization when assessing the impairment in either its mitigated or unmitigated state, as the Court assumed it would. ${ }^{206}$ The

202. Id. at $481-89$.

203. The Court never directly states that it is employing a Chevron analysis. Instead, it examines the statute to determine whether Congress intended that an impairment be examined in its mitigated, as opposed to its unmitigated, state. Compare id., with Food and Drug Admin. v. Brown \& Williamson Tobacco Corp., 529 U.S. 120, 132 (2000) ("Because this case involves an administrative agency's construction of a statute that it administers, our analysis is governed by Chevron.") (citation omitted).

204. The circuit courts confronting this issue largely agreed, finding the statutory language ambiguous. See supra note 15. See also Crossley, supra note 127, at 625 (describing statutory definition of disability as "notoriously, albeit intentionally, vague and thus subject to varying interpretations").

205. See supra notes $173-76$ and accompanying text; Samuel Issacharoff and Justin Nelson, Discrimination with a Difference: Can Employment Discrimination Law Accommodate the Americans with Disabilities Act? 15 (Apr. 2000) (unpublished manuscript, on file with author) ("This exercise in grammatical reasoning is a stretch, to say the least."); Kamholz, supra note 22, at 103-04 (explaining that the statutory language has at least three different meanings). But see Harris, supra note 22, at 603 (asserting that "substantially limits" precludes consideration in unmitigated state).

206. As the Court stated:

The agency approach would often require courts and employers to speculate about a person's condition and would, in many cases, force them to make a disability determination

based on general information about how an uncorrected impairment usually affects indi- 
record disclosed the twins' vision with glasses (virtually perfect) and without (legally blind); no hypothesizing was required. ${ }^{207}$ In fact, the twins were not hired by United because of their actual, not hypothetical, condition in its unmitigated state. ${ }^{208}$ Thus, to say that the statute requires a focus on the individual does little to advance resolution of the mitigating measures conundrum.

Finally, the " 43 million Americans" figure heavily relied upon by the Court proved only that Congress was remarkably imprecise if it was attempting to put a number on the individuals within the ADA's protected class. ${ }^{209}$ First, the Court could only speculate as to the report on which the figure was based. Second, that report itself described "the difficulty of estimating the number of disabled persons due to varying operational definitions of disability." ${ }^{10}$ No figure included in the report coincided with the 43 million figure cited by Congress. ${ }^{211}$ Moreover, the Court cited no figures for the number of persons whose unmitigated impairments substantially limit their major life activities; it cited figures only for the number of persons with impairments. In short, rather than being a critical clue to statutory meaning, the "findings" did little to clarify congressional intent on the matter. ${ }^{212}$ That the Court used them to supply a "plain meaning" to the statute was stunning.

The Court's construction of the statute has the perverse effect of eliminating relief against discrimination for those who have mitigated disabilities. Under Sutton, employers will be free to discriminate against individuals who have fully correctable physical or mental impairments, even when the employer is discriminating because of the impairments' effects in their unmitigated state. ${ }^{213}$ This result seems at

viduals, rather than on the individual's actual condition.

Sutton, 527 U.S. at 483. But see Issacharoff \& Nelson, supra note 205, at 16 ("[T]he Court's conclusion that an examination of the unmitigated condition would preclude an individualspecific inquiry ignores the actual, individualized evidence in the case before it.").

207. Sutton, 527 U.S. at 475.

208. Id.

209. The majority describes this number as "critical[]" to its interpretation. Id. at 484 . Justice Ginsburg's concurrence regards it as one of the "strongest clues" to Congressional intent. Id. at 494 (Ginsburg, J., concurring).

210. Id. at 485 .

211. Id. at $485-86$.

212. This aspect of Sutton has been described as "a peculiar connect-the-dots approach to statutory interpretation." Issacharoff \& Nelson, supra note 205, at 17 . As stated by Gary E. Phelan, one attorney interviewed about the decision, "I've never seen a court place such emphasis on language in a preamble. I think its more an indication that the Supreme Court majority] knew the answer they wanted to reach and had to find some rationale and that was one way to get there." Susan J. McGolrick, Supreme Court's Three ADA Decisions Disappoint Disability Rights Advocates, 68 U.S. LAW WEEK 2035, 2037 (July 20, 1999).

213. This point was brought forcefully home in Justice Stevens' dissent. As he stated: 
odds with congressional intent to bring such persons into the economic mainstream. ${ }^{214}$

Importantly, if the statute is to be considered as a whole in determining its meaning, as the Court insisted it must, ${ }^{215}$ then the scope of Title I of the ADA, the title under which the twin sisters sought the Act's protections, should have been considered. Recall that the employment Title of the ADA extends its protections only to a qualified individual with a disability, one who can perform essential job functions. ${ }^{216}$ Often, it is the mitigating measure that enables the individual to perform her job. Sutton and Hinton were not contending they were able to fly airplanes in their unmitigated state; they understood that whatever the reach of the ADA, it did not encompass putting blind pilots into the cockpits of commercial airliners. Rather, their claim was that because their eyeglasses enabled them to see, they were qualified to fly the plane, despite their myopia. Whether they were correct or incorrect in this assumption would seem a question best suited for an analysis of whether they were or were not qualified individuals with a disability. ${ }^{217}$ Resolving the case at the disability threshold preempted this inquiry.

The seven-justice majority opinion in Sutton reflects a triumph of a textualist methodology of statutory interpretation. ${ }^{218}$ If the operative language of the ADA possesses the requisite clarity vis-à-vis the mitigating measures issue, then it is difficult to imagine a statute not susceptible to resolution at Chevron's Step One under a textualist reading. ${ }^{219}$

The Court's refusal to consider the statute's legislative history when exploring the statute's meaning ${ }^{220}$ raises troubling questions about the consequences of applying a textualist approach at Step One of Chevron analysis. ${ }^{221}$ In the case of Sutton, extensive legislative his-

The Court's misdirected approach permits any employer to dismiss out of hand every person who has uncorrected eyesight worse than 20/100 without regard to the specific qualifications of those individuals or the extent of their abilities to overcome their impairment. In much the same way, the Court's approach would seem to allow an employer to refuse to hire every person who has epilepsy or diabetes that is controlled by medication, or every person who functions efficiently with a prosthetic limb.

Sutton, 527 U.S. 509 (Stevens, J., dissenting).

214. See sources cited supra note 172.

215. Id. at 482.

216. See supra note 126 and accompanying text.

217. Sutton, 527 U.S. at 510-11 (Stevens, J., dissenting).

218. See Tepker, supra note 33, at 184.

219. But see AT\&T Corp. v. Iowa Utils. Bd., 525 U.S. 366 (1999) (upholding some of FCC's challenged regulations at Step Two of Chevron).

220. Sutton, 527 U.S. at 482.

221. While reasonable people may disagree about how the statutory definition should best be interpreted, to find that Congress has directly spoken to the precise question at issue 
tory did, in fact, speak directly to the question at issue in the case..$^{222}$ As noted by Justice Stevens' dissent, multiple committee reports from both the House and Senate were "replete with references to the understanding that the Act's protected class includes individuals with various medical conditions that ordinarily are perfectly 'correctable' with medication or treatment." 223 Even if the Sutton majority is correct that a textualist reading of the ADA can reveal a clear congressional intent, the legislative history set forth in Sutton, together with the indeterminate statutory language, should have been sufficient to prevent the Court from rejecting the agency's view at Chevron's Step One. ${ }^{224}$

To be sure, disagreements within the Court long have simmered over the appropriate role of legislative history in determining statutory meaning. ${ }^{225}$ Yet the Sutton majority's refusal to address such relevant evidence of congressional intent reveals the extent to which a textualist methodology, which purports to be ideologically neutral, can both conceal and justify a great deal of judicial activism at Step One of Chevron analysis.

The Court has been increasingly willing to resolve interpretive questions at Chevron's Step One for years, thereby avoiding any need to defer to an agency's statutory interpretations. ${ }^{226}$ Sutton could be read as suggesting that an increasingly conservative Court is no longer

through its statutory language strains credulity. See Eichhorn, supra note 33, at 1108 ("First, and most importantly, the holding imposes a 'plain meaning' analysis upon statutory language that is far from plain."); Tepker, supra note 33, at 197 (criticizing the Sutton analysis as inconsistent with "the judicial virtue of fidelity to the text. This approach is exactly the kind of policy-laden presumption that the defenders of judicial restraint say they oppose."). But see Harris, supra note 22 , at 603 , who maintains that the ADA's language is not ambiguous on mitigating measures issue since the statute is written in the present tense. Harris also contends, however, that "it is not clear whether individuals with controlled impairments should benefit from the Act's protections," id. at 594, and that even if the Act's language were ambiguous, the EEOC guidelines are nevertheless inconsistent with some of the Act's "plain language." Id. at 603 . These contradictory contentions are puzzling. For a similar viewpoint, see Bridges, supra note 16, at 1073 (advocating resolution of mitigating measures issue at Step One of Chevron analysis); Michael J. Puma, Note, Respecting the Plain Language of the ADA: A Textualist Argument Rejecting the EEOC's Analysis of Controlled Disabilities, 67 GEO. WASH. L. REV. 123, 145 (1998) (use of present tense in "substantially limits" unambiguously requires consideration of mitigating measures).

222. See supra note 172 and accompanying text. As noted by the EEOC and the United States, "That expression of Congress's understanding, repeated in the three relevant committee reports on the ADA, is unusually clear and unequivocal, and it makes Congress's intent unmistakable." Brief for the United States and the Equal Employment Opportunity Commission as Amicus Curiae Supporting Petitioner at 10, Murphy v. United Parcel Serv., Inc., 527 U.S. 516 (1999) (No. 97-1992).

223. Sutton, 527 U.S. at 501 (Stevens, J., dissenting).

224. In his Sutton dissent, Justice Stevens used legislative history to resolve the interpretive issue at Step One in a manner consistent with the agency's reading of the statute. See Sutton, 527 U.S. at 499-503.

225. See Mank, supra note 21, at 532-33; Pierce, supra note 4, at 777; Tepker, supra note 33 , at 184 n.19.

226. See Mank, supra note 21 ; Pierce, supra note 4. 
willing to defer to what it perceives as more liberal agency agendas. ${ }^{227}$ The Court has not disavowed Chevron, however, and it subsequently has applied a straightforward Chevron analysis, albeit one that resolves the interpretive question at Chevron's Step One, in confronting an agency's construction of the statute it administers. ${ }^{228}$

Was there, then, something about the statute in question that made the Court's refusal to defer to the EEOC in Sutton consistent with a continuing commitment to a robust Chevron doctrine? A full critique of the decision in Sutton requires exploration of this latter point.

\section{THE POLITICS OF EMPLOYMENT DISCRIMINATION AND THE IMPACT ON CHEVRON}

Perhaps the Court believes that there is something about the statutes administered by the EEOC that makes Chevron deference to the agency somehow inappropriate. After all, the Supreme Court did more than simply fail to defer to the EEOC's interpretation in Sutton. It suggested that the EEOC's regulations concerning what constitutes a disability may be entitled to no deference at all ${ }^{229}$ and pointedly questioned the agency's regulatory conclusion that working is a major life activity, even though that regulatory approach is a well-accepted component of disability law. ${ }^{230}$

Why might the Court think that the EEOC is not entitled to meaningful deference? Perhaps it is the importance of Title VII, the ADEA and the ADA for citizens' liberty and autonomy that makes deference to an administrative agency on such issues unacceptable. ${ }^{231}$

227. One commentator has suggested the decision is best explained by an interpretive approach that defers to employer discretion. See Tepker, supra note 33, at 197. More broadly, perhaps the decision reflects shifts in political winds since Chevron was decided. A conservative judiciary may be unwilling to support the views of a Democratic administration. Pierce, supra note 4 , at 780 .

228. See Food \& Drug Admin. v. Brown \& Williamson Tobacco Corp., 529 U.S. 120, 133-43 (2000) (looking at statute as a whole, together with legislative history, in finding that Congress intended to preclude the FDA's regulation of tobacco).

229. Sutton, 527 U.S. at 480 . The Sutton Court's approach to the EEOC's regulations on the definition of disability may be contrasted with the Bragdon Court's approach to the Justice Department's regulations on disability. While the Court declined to decide whether the Justice Department's regulations would receive Chevron deference, it found they at the least were entitled to deference under Skidmore. See supra note 156 and accompanying text; Befort \& Thomas, supra note 9, at 94-97 (contrasting the Bragdon Court's deferential approach with that exhibited in Sutton); Eichhorn, supra note 33, at 1110 (noting this aspect of Sutton "indeed reinforces the idea that the EEOC is wrongly receiving second-class treatment at the hands of the courts").

230. 45 C.F.R. $\S 84.3(j)(2)(i i)$ (1999); 28 C.F.R. $\$ 41.31$ (b)(2) (1999). This reservation was noted by the Sutton Court, despite the ADA's directive that ADA standards be no less protective than regulations adopted under the Rehabilitation Act. See supra notes 99-100 and accompanying text.

231. See Befort \& Thomas, supra note 9, at 73-74 (suggesting that the policy choices underlying the ADA may tempt some judges to exercise their own discretion rather than defer 


\section{A. Administrative Agencies, Civil Rights, and Chevron}

The issue of discrimination, particularly race discrimination, is the most intractable problem confronting American society. How that issue is best confronted and resolved in the employment setting has consequences for virtually every U.S. business, as well as for almost every U.S. employee. Although Congress, in passing Title VII, the ADEA, and the ADA, has made basic and important policy choices in outlawing employment discrimination, the ultimate reach of antidiscrimination laws depends on how those laws are interpreted and applied. ${ }^{232}$

If the Court means what it said in Chevron, however, the importance of the policy choices involved in the interpretation of a particular statute should support, not detract from, an agency's claim to deference. ${ }^{233}$ After all, it was the need for important policy choices to be made by a politically accountable branch of government, rather than by politically unaccountable courts, that led the Chevron court to divine a delegation of interpretive authority from statutory silence or ambiguity. ${ }^{234}$ If so, the importance of the policy choices involved in the interpretation of Title VII, the ADEA and the ADA should have resulted in more, not less, deference to the EEOC's interpretation of the statutes it administers and enforces.

The Court's experience with the EEOC, however, has centered primarily around Title VII of the Civil Rights Act. ${ }^{235}$ The theoretical underpinnings of Chevron notwithstanding, the Supreme Court simply may be unwilling to permit an administrative agency to roam within a

to the agency).

232. See Harold J. Krent, Delegation and Its Discontents, 94 Colum. L. REV. 710, 729 (1994) (reviewing DAVID SCHOENBROD, POWER WITHOUT RESPONSIBILITY (1993)).

233. See Chevron U.S.A., Inc. v. Natural Res. Def. Council, Inc., 467 U.S. 837 (1984):

While agencies are not directly accountable to the people, the Chief Executive is, and it is entirely appropriate for this political branch of the Government to make such policy choices - resolving the competing interests which Congress itself either inadvertently did not resolve, or intentionally left to be resolved by the agency charged with the administration of the statute in light of everyday realities.

Id. at 865-66.

Judicial deference to an agency's interpretation of ambiguous provisions of the statutes it is authorized to implement reflects a sensitivity to the proper roles of the political and judicial branches.... As Chevron itself illustrates, the resolution of ambiguity in a statutory text is often more a question of policy than of law.

Pauley v. Bethenergy Mịes, Inc., 501 U.S. 680, 696 (1991).

234. See Pauley, 501 U.S. at 696; Diver, supra note 18, at 593-95; Daniel A. Farber, Legislative Deals and Statutory Bequests, 75 MINN. L. REV: 667, 678 (1991); Kmiec, supra note 4, at 277; Manning, supra note 41, at 625; Merrill, supra note 4, at 993-1003; Scalia, supra note 4, at 515; Starr, supra note 4, at 309, 312.

235. See White, supra note 2, at 71-76 (describing the Court's deference to the EEOC under Title VII). 
wide range of "reasonable" action in determining the parameters of antidiscrimination law. After all, Chevron requires a reviewing court to uphold an agency interpretation the court itself believes is secondbest, so long as that interpretation is reasonable. ${ }^{236}$ In the sensitive area of race or sex discrimination, the Supreme Court may be unwilling to defer to an agency interpretation with which it disagrees. Perhaps the Court senses that Title VII has needed the imprimatur of the courts behind it for the statute's basic mandates to be accepted. ${ }^{237}$

Essentially, despite its failure to say it in so many words, perhaps the Court believes the deference principles of Chevron are inapplicable to a statute, such as Title VII, whose interpretation intimately affects the civil rights of virtually every working man and woman. ${ }^{238}$ Whether Title VII embraces the concept of disparate impact, ${ }^{239}$ whether, and under what circumstances, an employer may engage in affirmative action, ${ }^{240}$ and whether the prohibitions of Title VII encompass discrimination on the basis of pregnancy ${ }^{241}$ or sexual harassment ${ }^{242}$ are fundamentally more important to defining the scope of individual rights than is the definition of a "stationary source" under the Clean Air Act. ${ }^{243}$ In short, perhaps there is an outer limit to Chevron's approach to political accountability. If so, the Supreme Court may believe Title VII lies outside it.

Congress's failure to confer substantive rulemaking authority on the EEOC under Title VII could be understood as endorsing this view. Although this interpretation is inconsistent with a strong reading of Chevron, i.e., one that would not find Chevron review dependent upon a delegation of rulemaking authority, ${ }^{244}$ it is a possible explana-

236. Chevron, 467 U.S. at $842-43$.

237. James A. Goldston, Race Discrimination in Europe: Problems and Prospects, 5 EUR. HUM. RTS. L. REV. 462 (1999):

Under certain circumstances, judicial decisions may have more moral authority than purely political decisions, precisely because - however true it is - the law is seen by many to rest on more neutral considerations of justice and right than the crass or petty concerns which motivate hand-slapping politicking in smoke-filled rooms.

Id. at 464.

238. See Wern, supra note 3 , at 1579 (asserting that perhaps the Court wants Congress to make "these sensitive policy decisions" and thus refuses to defer to the EEOC despite statutory ambiguity). It may be true, but it is beside the point. If a statute is ambiguous, its interpretation involves policymaking that will be accomplished not by Congress but by the Court, if deference to the agency does not occur.

239. See Griggs v. Duke Power Co., 401 U.S. 424 (1971).

240. See United Steelworkers of Am. v. Weber, 443 U.S. 193 (1979).

241. See General Elec. Co. v. Gilbert, 429 U.S. 125 (1976).

242. See Meritor Sav. Bank v. Vinson, 477 U.S. 57 (1986).

243. Chevron involved review of the EPA's interpretation of the term "source" in the Clean Air Act. Chevron U.S.A., Inc. v. Natural Res. Def. Council, Inc., 467 U.S. 837, 839-40 (1984).

244. In a previous article, I have explained why the EEOC's lack of substantive rule- 
tion for the Court's unwillingness to give meaningful deference to the EEOC under Title VII.

But what of the ADEA or the ADA? Congress did confer substantive rulemaking authority under those statutes, reflecting a clear congressional intent to have the agency fill in the statutory gaps. ${ }^{245}$ Why might Congress have been willing to give an administrative agency a leading role under those statutes, if it was unwilling to do so under Title VII?

Unlike race and gender classifications, age and disability classifications are not immutable. All of us, should we be lucky to live long enough, will ultimately fall within the ADEA's protected class. And each of us who is not already a member is potentially a member of the ADA's protected class. The potential applicability of age or disability classifications to every citizen suggests that such interests may be relatively more likely to receive protection through the political process. ${ }^{246}$ Congress may have been willing, as exemplified by its decision to confer substantive rulemaking authority on the EEOC, to have a politically accountable agency resolve interpretive questions arising under the ADA.

In addition, the issues raised by the ADA in particular are of the sort that often demand a technical expertise not required by Title VII. ${ }^{247}$ Deciding how jobs should be restructured or buildings reconfigured is a daunting task, as evidenced by the volumes of materials, including technical assistance manuals, produced by the agencies charged with carrying out the statute's mandates. ${ }^{248}$ To the extent that

making authority under Title VII should not be viewed as foreclosing the agency's claim to Chevron review of its interpretations of that statute. White, supra note 2, at 92-102. I argued that the agency's enforcement power supported an implicit delegation of interpretive authority, even though the power to issue new obligations through legislative rules had been withheld. Id. However, as I conceded, finding Chevron applicable to the EEOC's interpretations of Title VII is more difficult than applying Chevron to the agency's interpretations of the ADEA and the ADA. Id. at 92.

245. See 29 U.S.C. $\$ 628$ (1994); 42 U.S.C. § 12116 (1994).

246. But see infra notes 253-254 and accompanying text.

247. Cf. Wern, supra note 3 , at 1579 , who suggests the lack of technical complexity of the statutes administered by the EEOC may explain the lack of deference extended to the agency by the courts. As he states,

The EEOC's domain, employment discrimination, is not an arena that requires such technical expertise; rather, logic and basic fairness concerns may dominate decisionmaking in this area. Simply put, judges believe that they do not need an agency telling them who has or has not suffered wrongful discrimination; yet they welcome agency guidance in technical areas where judicial reasoning is not sufficient.

Id; see also Befort \& Thomas, supra note 9, at 68, 73-74.

248. See 29 C.F.R. pt. 1630 (1999); 28 C.F.R. pt. 35 (1999); 28 C.F.R. pt. 36 (1999); 49 C.F.R. pt. 37 (1999); EEOC, A TECHNICAL AsSistanCE MANUAL ON THE EMPLOYMENT PROVISIONS (TITLE I) OF THE AMERICANS WITH DISABILITIES ACT (1992); U.S. DEP'T OF Justice, The AmeriCANS With Disabilities ACT: Title II TeChNiCAL AsSistance MANUAL (1993); U.S. DEP'T OF JUSTICE, THE AMERICANS WITH DISABILITIES ACT: TITLE III TECHNICAL ASSISTANCE MANUAL (1993). 
agency expertise is a premise of the Chevron doctrine,${ }^{249}$ the ADA is a prime candidate for application of Chevron review principles.

And yet the Court has been reluctant to agree. Perhaps the explanation lies in the Court's unwillingness to surrender Fourteenth Amendment turf to another branch of government.

In enacting the ADA, Congress expressly relied upon its powers under Section 5 of the Fourteenth Amendment when extending the ADA to the states. ${ }^{250}$ Congress, moreover, described individuals with disabilities as a "discrete and insular minority," 251 a description Justice Ginsburg noted in her Sutton concurrence. ${ }^{252}$ The Court since has held that Title I of the ADA was not a valid exercise of congressional power under the Fourteenth Amendment. ${ }^{253}$

Although the Court extends Congress "much deference" in determining whether legislation is needed to enforce the Fourteenth Amendment, "[t]he ultimate interpretation and determination of the Fourteenth Amendment's substantive meaning remains the province of the Judicial Branch."254 The Court is not about to allow Congress to supply substantive meaning to the Fourteenth Amendment by determining which groups are, or are not, "discrete and insular minorit[ies]" for Fourteenth Amendment purposes; ${ }^{255}$ and if Congress it-

249. Chevron review is justified, in part, "because of the agency's greater familiarity with the ever-changing facts and circumstances surrounding the subjects regulated." Food and Drug Admin. v. Brown \& Williamson Tobacco Co., 529 U.S. 120, 132 (2000). See also Saunders, supra note 82, at 362 (questions that are technical in nature or that call for agency expertise suggest an implicit delegation of interpretive authority). But see Duffy, supra note 18 , at 203 (describing agency expertise and political accountability as "mere window dressing" for Chevron deference); Scalia, supra note 4, at 514 ("[Agency expertise means that the agency is] more likely than the courts to reach the correct result. That [argument] is, if true, a good practical reason for accepting the agency's views, but hardly a valid theoretical justification for doing so.").

250. 42 U.S.C. $\$ 12101(b)(4)$ (1994).

251. 42 U.S.C. $\$ 12101(\mathrm{a})(7)(1994)$.

252. See Sutton v. United Air Lines, Inc., 527 U.S. 471, 494 (1999) (Ginsburg, J., concurring).

253. University of Alabama at Birmingham v. Garrett, $121 \mathrm{~S}$. Ct. 955 (2001). The Fourteenth Amendment issue arises in the wake of the Court's decision in Seminole Tribe of Florida v. Florida, 517 U.S. 44 (1996), in which the Court held that Congress may waive a nonconsenting state's immunity from citizen suits only when enacting legislation pursuant to Section 5 of the Fourteenth Amendment. Since Congress expressed an unequivocal intent to abrogate states' immunity from suit under the ADA, the question becomes whether the $\mathrm{ADA}$ was a valid exercise of congressional power under the Fourteenth Amendment. If the answer is no, the substantive commands of the statute vis-à-vis the states still stand; enforcement of the ADA against nonconsenting states through private litigation, however, would be foreclosed.

254. Kimel v. Florida Board of Regents, 528 U.S. 62, 81 (2000).

255. See Robert C. Post \& Riva B. Siegel, Equal Protection by Law: Federal Antidiscrimination Legislation After Morrison and Kimel, 110 YALE L. J. 441 (2000) (criticizing Court for holding Congress to a litigation model in enacting legislation under the Fourteenth Amendment). 
self lacks that interpretive power, then Congress cannot delegate that power to an administrative agency. Perhaps the Sutton Court's unwillingness to allow the EEOC to flesh out the meaning of "disability" reflects a concern with perceived congressional overreaching into the Court's constitutional turf.

But such concerns, if they were driving the Sutton Court, were misplaced. Congress has the clear power under the Commerce Clause to enact the ADA and to apply it to the private and public sector workplace. ${ }^{256}$ And the agency's responsibility is to interpret the statute that Congress constitutionally enacted. That statute, as interpreted by the agency, in fact may exceed Congress's Fourteenth Amendment powers as applied to the states. Statutory commands may and often do exceed constitutional prohibitions.

Yet it remains the Court's role to determine whether the statute exceeds congressional power under the Fourteenth Amendment, thereby leaving the States' Eleventh Amendment immunity intact. That the agency supplies meaning to the statute in no way interferes with the Court's authority to determine whether the statute, as written by Congress and interpreted by the agency, goes beyond Congress's Fourteenth Amendment powers. Chevron review of agency interpretation of statutes enacted under the Fourteenth Amendment does not encroach on the Court's authority to interpret the Constitution. To view the Fourteenth Amendment parallel as a basis for refusing to defer to the EEOC's construction of the statute it administers is to deprive the politically accountable branches of government the power to determine the substantive reach of statutory, not constitutional, commands.

In summary, the EEOC, particularly (although not exclusively) in the context of the ADA, is an agency deserving of Chevron review when interpreting the statute. It "makes sense" in the context of the ADA to believe Congress preferred that interpretive issues left unresolved by the statute be untangled by an expert agency sensitive to the technical complexities of the statutory scheme and better able to resolve policy choices inevitable in the implementation of a complex statute. ${ }^{257}$ Because a delegation of interpretive authority to the EEOC under Title I may readily be found, the EEOC's interpretations of Title I's gaps and ambiguities generally are entitled to Chevron review.

256. See id. at 78 (recognizing congressional power under the Commerce Clause to enact the ADEA and to extend it to the states). There is no reason to believe a different result would obtain under the ADA vis-à-vis Congress's Commerce Clause power. See Garrett, 121 S. Ct. at 968 n.9 (2001).

257. See Breyer, supra note 61, at 370 (Chevron deference is appropriate when a statutory scheme suggests that Congress intended that agencies, not courts, resolve statutory ambiguities). 


\section{B. Chevron's Step One: A Kind of Nondelegation Doctrine?}

To say, however, that the EEOC generally is deserving of Chevron deference when interpreting statutory ambiguities in the ADA does not mean that the Court necessarily should have deferred to the EEOC in Sutton. Application of Chevron instead demands a careful look at the particular interpretive issue posed.

In its most recent application of Chevron, the Supreme Court suggested that the importance of the question posed may "in extraordinary cases" influence the Court's application of Chevron. ${ }^{258}$ As the Court stated,

[O]ur inquiry into whether Congress has directly spoken to the precise question at issue is shaped, at least in some measure, by the nature of the question presented. Deference under Chevron to an agency's construction of a statute that it administers is premised on the theory that a statute's ambiguity constitutes an implicit delegation from Congress to the agency to fill in the statutory gaps. In extraordinary cases, however, there may be reason to hesitate before concluding that Congress has intended such an implicit delegation. ${ }^{259}$

Even though Congress may generally have delegated interpretive authority to an agency, and a Chevron review standard is appropriately applied, the significance of the policy choice represented by a particular interpretive question may shape the Court's application of Chevron's Step One.

In Brown \& Williamson, for example, the Court was confronted with the FDA's contention that tobacco was a "drug" and that tobacco products were thus subject to regulation by the agency ${ }^{260}$ Acknowledging that Congress delegated to the FDA the authority to interpret the Food, Drug and Cosmetic Act, and that a Chevron analysis therefore was applicable ${ }^{261}$ the Court went on to reject the agency's construction at Step One of Chevron. ${ }^{262}$ In doing so, the Court openly relied upon the importance of the policy question presented. In finding that Congress had spoken directly to the precise question at issue and had precluded the FDA's authority to regulate tobacco products, the Court tellingly observed, "we are confident that Congress could not have intended to delegate a decision of such economic and political significance to an agency in so cryptic a fashion." ${ }^{.263}$

258. Food and Drug Admin. v. Brown \& Williamson Tobacco Co., 529 U.S. 120, 159 (2000).

259. Id. (citation omitted).

260. Id. at 131.

261. Id at 132. The Court's application of Chevron analysis to this question would seem to silence those who contend that Chevron is inapplicable to jurisdictional questions.

262. Id. at 133.

263. Id. at 160. This approach makes sense when one recalls that Chevron is best understood as a reconstruction of congressional intent. If the Court does not believe Congress in- 
Is this acknowledgment that some important policy questions must be legislatively resolved the best explanation for the Sutton holding? Finding "clear" congressional meaning when particularly significant policy questions are presented allows the Court to avoid reinvigorating the nondelegation doctrine, something the Court has been loathe to do. ${ }^{264}$ Were the Court to find a delegation of interpretive authority on questions of such economic and political significance, it would be forced to confront whether that delegation violates separation of powers concerns. ${ }^{265}$ Construing a statute so as to avoid a constitutional issue is a longstanding tool of statutory construction, appropriately applied at Chevron's Step One. ${ }^{266}$

But is the definition of disability such a question? Certainly, how broadly or narrowly one construes the statutory definition has considerable implications for the statute's impact. Being an individual with a disability is a threshold coverage issue. Whether the statute, for example, potentially protects 43 million, or over 160 million, persons ${ }^{267}$ has obvious significance for the statute's reach. ${ }^{268}$

And yet even under the most expansive definition, the ADA's protections sweep no more broadly than other employment statutes under which interpretive authority has been delegated. ${ }^{269}$ Deciding the scope of protection under the Family and Medical Leave Act, ${ }^{270}$ or the extent

tended to delegate interpretive authority, no deference to the agency should occur. See Sunstein, supra note 4, at 2085-2105. And when an issue is particularly important, it may be less likely that Congress chose not to resolve the issue itself. See Breyer, supra note 61 , at 370 .

264. American Textile Mfrs. Inst., Inc. v. Donovan, 452 U.S. 490, 538 (1981).

265. For discussions of Chevron's interplay with the nondelegation doctrinee, see Kmiec, supra note 4, and Richard J. Pierce, Jr., The Role of Constitutional and Political Theory in Administrative Law, 64 TEXAS L. REV. 469 (1985). In a separate article, Professor Pierce has suggested the Court's narrow interpretation of broad statutes may be a means of avoiding the nondelegation doctrine. Pierce, supra note 4, at 776.

266. Edward J. DeBartolo Corp. v. Florida Gulf Coast Bldg. \& Constr. Trades Council, 485 U.S. 568, 574-78 (1988) (construing statute governing handbilling at mall entrances so as not to conflict with First Amendment). See Sunstein, supra note 4, at 2110-12.

267. See Sutton v. United Air Lines, Inc., 527 U.S. 471, 485-86 (1999).

268. In a similar vein, it has been suggested that the uncertainty of employer obligations under the ADA, most notably the uncertainty of the contours of the duty of reasonable accommodation, may have influenced the Sutton Court's narrow approach to the disability question. "The Court is straining the wording of all three prongs of the statute so much because the definition of disability is the ballgame." Issacharoff \& Nelson, supra note 205, at 22. The authors assert that the Court uses the definition of disability as a filter to avoid imposing the "inherently ambiguous" duty of reasonable accommodation on employers. Id.

269. Generally speaking, one must be an individual with a disability to receive protections under the ADA. Other employee protective statutes sweep far more broadly, covering most workers.

270. 29 U.S.C. $\$ 2611$ (1994); Manuel v. Westlake Polymers Corp., 66 F.3d 758, 763 (5th Cir. 1995) ("Administrative regulations promulgated in response to express delegations of authority, like the one at issue [in FMLA], 'are given controlling weight unless they are arbitrary, capricious, or manifestly contrary to the statute." " (quoting Chevron U.S.A. v. Natural Res. Def. Council, Inc., 467 U.S. 837, 844 (1984)). 
of the "white collar worker" exemptions of the Fair Labor Standards Act, ${ }^{271}$ or who constitutes an employee under the National Labor Relations Act, ${ }^{272}$ or establishing health and safety standards under the Occupational Safety and Health Act, ${ }^{273}$ all involve significant policy questions for the employment community.

That Congress was willing to allow agency interpretation to shape the disability definition is explicitly supported by the text of the ADA. Congress determined that the ADA should be no less protective than "the regulations issued by Federal agencies pursuant to" the Rehabilitation Act. ${ }^{274}$ Although this provision admittedly is not an express delegation of interpretive authority to any particular agency under the ADA,${ }^{275}$ the admonition is consistent with congressional willingness to allow administrative agencies to flesh out the details of an inherently ambiguous statutory definition. Determining the parameters of what constitutes a disability, Congress understood, is a topic well-suited to development through administrative expertise.

Most important, the Court itself failed to invoke the "economic and political significance" of the ADA as an explanation for its approach at Step One of Sutton. The Court apparently did not view (and should not have viewed) the definition of disability as the extraordinary case in which a delegation of interpretive authority should be suspect. Accordingly, further explanation for the failure to defer to the EEOC must be explored.

\section{DEFERENCE AND DISABILITY DISCRIMINATION: RETHINKING SUTTON V. UNITED AIR LINES}

As stated above, the magnitude of the interpretive issues presented by the Americans with Disabilities Act is an insufficient basis for not extending deference to agency interpretations of the statute. But that does not resolve whether the particular interpretive issue presented in Sutton was a legitimate candidate for Chevron deference. If the Court may be faulted for its textualist approach in Sutton, how should the Court have resolved the interpretive issue presented?

271. Fair Labor Standards Act, 29 U.S.C. $\$ 213$ (1994); Auer v. Robbins, 519 U.S. 452, 457 (1997) (applying Chevron analysis to Secretary of Labor's salary basis test).

272. 29 U.S.C. § 152(3) (1994); Holly Farms Corp. v. Nat'l Labor Relations Bd., 517 U.S. 392 (1996) (deferring to NLRB's interpretation of agricultural worker exemption).

273. 29 U.S.C. $\$ 655(b)(5)$ (1994); American Textile Mfrs. Inst., Inc. v. Donovan, 452 U.S. 490 (1981) (upholding OSHA's cotton dust standard).

274. 42 U.S.C. $\$ 12201$ (a) (1994).

275. Section 12201 is found in the Act's miscellaneous provisions. Nonetheless, an argument can be made that it should be viewed as a delegation of authority to the EEOC, the Justice Department, and the Secretary of Transportation to interpret not only the statute but the regulations issued under the Rehabilitation Act. See Pauley v. Bethenergy Mines, Inc., 501 U.S. 680, 697-98 (1991). 


\section{A. The Definition of Disability: Was There a Delegation of Interpretive Authority to the EEOC?}

In order for Chevron review to apply, the Court must find an express or implicit delegation of interpretive authority to the agency. Title I of the ADA confers on the EEOC the authority to promulgate regulations to carry out that Title, a grant of authority commonly understood to support an express or implicit delegation of interpretive authority. ${ }^{276}$ The statutory definition of disability, however, is not found within Title I. Instead, that definition appears in the Act's general definition section. ${ }^{277}$

No agency has been expressly delegated authority to promulgate rules interpreting this section of the statute. ${ }^{278}$ Further complicating matters is the delegation of interpretive authority to multiple agencies under the ADA. While the EEOC has been delegated rulemaking authority under Title I of the statute, ${ }^{279}$ the Justice Department ${ }^{280}$ and the Department of Transportation ${ }^{281}$ have been delegated rulemaking authority under other Titles of the Act. The Act's general definition section, including its definition of an individual with a disability, applies to each of the Act's Titles. ${ }^{282}$

In Bragdon v. Abbott and again in Sutton, the Court suggested that Congress's failure expressly to confer on any agency the authority to promulgate rules interpreting the Act's general definition section may mean no agency is deserving of deference when interpreting who is an individual with a disability. ${ }^{283}$ Thus, while the EEOC, for example, would be deserving of Chevron deference when interpreting ambiguities or filling in statutory gaps in Title I, its extensive regulations fleshing out the meaning of an individual with a disability may be deserving of no deference whatsoever. Unless Congress delegated interpretive authority to the agency, it is not entitled to deference under

276. See supra notes $77-81$ and accompanying text.

277. 42 U.S.C. $\$ 12102(2)$ (1994).

278. See Sutton v. United Air Lines, Inc., 527 U.S. 471, 479 (1999) ("Most notably, no agency has been delegated authority to interpret the term 'disability.'").

279. 42 U.S.C. $\$ 12116$ (1994).

280. See 42 U.S.C. $\S 12134$ (1994); 42 U.S.C. $§ 12186($ b) (1994).

281. See 42 U.S.C. $\$ 12143$ (1994); 42 U.S.C. $\$ 12149$ (1994); 42 U.S.C. § 12164 (1994); 42 U.S.C. $\$ 12186(\mathrm{a})(1994)$.

282. 42 U.S.C. $\$ 12102$ (1994).

283. See Sutton, 527 U.S. at $478-80$ (noting authority to issue regulations under the ADA "is split primarily among three Government agencies ... we have no occasion to consider what deference [these regulations] are due, if any."); Bragdon v. Abbott, 524 U.S. 624, 642 (1998) ("Responsibility for administering the Rehabilitation Act was not delegated to a single agency, but we need not pause to inquire whether this causes us to withhold deference to agency interpretations under Chevron...."). 
Chevron, as Chevron review is premised on a theory of implied delegation. ${ }^{284}$

Did such a delegation occur? Justice Breyer's dissent in Sutton resolved this conundrum as follows: Congress delegated authority to the EEOC to promulgate regulations interpreting Title I. Title I, in turn, extends its protections to a "qualified individual with a disability."285 Thus, the EEOC has authority to promulgate regulations concerning the meaning of a "disability" in order to carry out the provisions of Title I. ${ }^{286}$ As he noted,

An EEOC regulation that elaborated on the meaning of this use of the word "disability" would fall within the scope both of the basic definitional provision and also the substantive provisions of "this" later subchapter, for the word "disability" appears in both places.

There is no reason to believe that Congress would have wanted to deny the EEOC the power to issue such a regulation, at least if the regulation is consistent with the earlier statutory definition and with the relevant interpretations by other enforcement agencies. The physical location of the definitional section seems to reflect only drafting or stylistic, not substantive, objectives. And to pick and choose among which of "this subchapter['s]" words the EEOC has the power to explain would inhibit the development of law that coherently interprets this important statute. $^{287}$

The majority's response to Justice Breyer's position was to dismiss it as an "imaginative interpretation of the Act's delegation provision ... belied by the terms and structure of the ADA." ${ }^{288}$ But the Court should not have dismissed Justice Breyer's position out of hand. Rather, his is a reasoned approach to the delegation question that is consistent with the terms and structure of the ADA.

Title I, the employment Title of the ADA, generally restricts its protections to one who is a "qualified individual with a disability."289 The definition section of Title I defines that term to mean "an individ-

284. See supra notes 59-60 and accompanying text.

285. 42 U.S.C. \& 12111(8) (1994).

286. See Sutton, 527 U.S. at 513-15. The Justice Department made a similar argument for deference to its Title III regulations in its amicus brief to the Court in Bragdon v. Abbott. See Brief for the United States as Amicus Curiae Supporting Respondents at $10 \mathrm{n.3}$, Bragdon v. Abbott, 524 U.S. 624 (1998) (97-156). Curiously, the Court appeared more receptive to the argument in Bragdon than in Sutton. See supra note 229 and accompanying text.

287. See Sutton, 527 U.S. at 514-15 (Breyer, J., dissenting).

288. Id. at 479.

289. 42 U.S.C. $§ 12112(a)$ (1994). I say "generally" because Title I also protects individuals from discrimination because of their relationship to or association with an individual with a disability. 42 U.S.C. $\S 12112(\mathrm{~b})(4)$. Title I also broadly prohibits preemployment medical inquiries and disclosure of medical information; courts have found that nondisabled employees may bring claims for violations of these provisions. See, e.g., Cossette v. Minn. Power \& Light, 188 F.3d 964, 969 (8th Cir. 1999). 
ual with a disability who, with or without reasonable accommodation, can perform the essential job functions of the employment position that such individual holds or desires." ${ }^{290}$ By delegating to the EEOC the authority to explain the meaning of Title I, Congress necessarily conferred on the agency the power to flesh out the meaning of this most important provision. Of course, its interpretation must be measured against the statutory language in the general definition section, but that does not deprive the agency of authority to bring those words to life within the meaning of Title I. Importantly, the agency's regulations and Interpretive Guidance plainly state that they are issued for the purpose of implementing Title I's provisions pertaining "to the employment of qualified individuals with disabilities."291

This argument makes particular sense when we understand that the EEOC is not purporting to give meaning to the term "individual with a disability" for the full panoply of circumstances in which the ADA applies. Rather, the EEOC necessarily is interpreting the term in the context of the employment provisions of the ADA. That Title does not protect all persons with a disability, but only those with a disability who are qualified for their jobs. ${ }^{292}$ The EEOC's understanding of who is an individual with a disability is understandably and correctly influenced by Title I's refinement of the term.

This approach, however, suggests that the meaning of disability may vary depending upon which Title of the ADA is being invoked. Could one be an individual with a disability for some Titles of the ADA but not for others?

Perhaps. For example, mitigating measures may be what enable an individual to perform essential job functions and thus render her a qualified individual with a disability. ${ }^{293}$ If so, assessment of her condition in its unmitigated state to determine whether she has a disability makes sense in the context of Title I, as it is merely a first step in determining protected class status. ${ }^{294}$ Under Title III, however, which

290. 42 U.S.C. $\$ 12111(8)$ (1994).

291. 29 C.F.R. \& 1630.1(a) (1999).

292. But cf. School Bd. of Nassau County v. Arline, 480 U.S. 273, 285 (1987) ("The definition of 'handicapped individual' is broad, but only those individuals who are both handicapped and otherwise qualified are eligible for relief.").

293. In Sutton, for example, the twins were not contending that they were qualified to fly an airplane in their unmitigated state. It was their eyeglasses that enabled them, so they claimed, to perform the job's essential functions. See Sutton, 527 U.S. at 503-04 (Stevens, J., dissenting).

294. As Justice Stevens correctly noted,

[Sutton] ... is not about whether petitioners are genuinely qualified or whether they can perform the job of an airline pilot without posing an undue safety risk. The case just raises the threshold question whether petitioners are members of the ADA's protected class. It simply asks whether the ADA lets petitioners in the door in the same way as the Age Discrimination in Employment Act of 1967 does for every person who is at least 40 years old . . . and as Title VII of the Civil Rights Act of 1964 does for every single individual in the work force. 
does not limit its protections to qualified individuals with disabilities, but instead protects individuals with disabilities, it is sensible to assess a condition in its mitigated state. ${ }^{295}$ Determining whether a place of public accommodation is accessible and usable by individuals with a disability logically may be made after taking mitigating measures into account. If medicine or mitigating measures routinely allow individuals with a particular impairment to use a facility without a problem, it makes little sense to require the facility to be designed for use in the impairment's unmitigated state.

Accordingly, that the term "individual with a disability" is not found within Title $I$ is not sufficient reason to deprive the EEOC of Chevron deference when it is interpreting that term in the context of Title $\mathrm{I}^{296}$ By delegating to the agency the authority to promulgate regulations interpreting Title I, Congress gave the agency the power to flesh out the parameters of Title I's protected class.

\section{B. The Question of Format}

Although Congress gave the EEOC the power to issue substantive regulations to carry out Title I of the ADA, and although the EEOC did promulgate such regulations, its position on the "mitigating measures" question appears in an Interpretive Guidance that accompanied the regulations, not in the regulations themselves. ${ }^{297}$ Was the format of the interpretation a basis for not deferring to the EEOC under Chevron ${ }^{298}$ Put another way, does Chevron review apply only to an agency's regulations, and not to interpretations expressed in less formal formats, as some commentators assert? ${ }^{299}$ The Court reserved this issue in Sutton.

This, too, is a question on which lower courts disagree. ${ }^{300}$ Some believe the format in which an agency interpretation appears is irrele-

\section{Id. at 504 (citation omitted).}

295. 42 U.S.C. $\$ 12182$ (1994).

296. Nor should the fact that more than one agency has been delegated authority to interpret the general definition matter. As one commentator has explained, "If Congress grants multiple agencies substantive rulemaking powers, then the court should review the regulations of each agency by trying to harmonize the statute and the regulations. The separate sets of rules would be like separate subchapters of a statute, each supplementing more general provisions found in the law." Duffy, supra note 18, at 208.

297. See supra note 13 and accompanying text.

298. Sutton, 527 U.S. at 480 ("Although the parties dispute the persuasive force of these interpretive guidelines, we have no need in this case to decide what deference is due.").

299. See DAVIS \& PIERCE, supra note 38, at 119-20; Harris, supra note 22, at 602; Hernandez, supra note 22, at 334-35; Herz, supra note 41, at 190; Yavelberg, supra note 82, at 186. But see Scalia, supra note 4, at 519 (arguing that the format in which interpretation appears does not matter).

300. Arnold v. United Parcel Serv., Inc., 136 F.3d 854 (1st Cir. 1998) (Interpretive Guidance gets Skidmore deference); Washington v. HCA Health Servs. of Tex., Inc., 152 F.3d 464 
vant, so long as the agency has been delegated interpretive authority. ${ }^{301}$ This approach, however, is misguided. Before deference to an agency's statutory interpretation should occur, a court must be satisfied that the agency intended to exercise the authority it was delegated. ${ }^{302}$ There is a significant difference between an agency interpretation pronounced in an amicus brief or opinion letter and an interpretation that issues after notice and comment procedures have been followed. ${ }^{303}$

The Supreme Court confirmed as much in its 1999 Term. In Christensen v. Harris County, ${ }^{304}$ the Court refused to apply Chevronstyled deference to a Department of Labor opinion letter. Such interpretations, said the Court, are entitled to Skidmore, not Chevron, review.

When an interpretation issues after informal rulemaking procedures have been followed, however, whether the interpretation is expressed in a regulation or in an Interpretive Guidance should make no difference. As the Christensen Court observed, Chevron review is reserved for interpretations "arrived at after, for example, a formal adjudication or notice-and-comment rulemaking." 305 Importantly, an interpretation promulgated after notice and comment procedures

(5th Cir. 1998) (Interpretive Guidelines entitled to Skidmore, not Chevron, deference); Gilday v. Mecosta County, 124 F.3d 760 (6th Cir. 1997) (interpretive rule gets Skidmore deference); Sutton v. United Air Lines, Inc., 130 F.3d 893 (10th Cir. 1997) (will give Chevron deference only to regulations, not to Interpretive Guidance); Harris v. H \& W Contracting Co., 102 F.3d 516 (11th Cir. 1996) (Interpretive Guidance gets Chevron deference). At the time the court decided Sutton, the Supreme Court had noted, but not resolved, this question. See City of Chicago v. Envtl. Def. Fund, 511 U.S. 328, 339 n.5 (1994) ("[W]e need not consider whether an agency interpretation expressed in a memorandum like the Administrator's in this case is entitled to any less deference under Chevron than an interpretation adopted by rule published in the Federal Register, or by adjudication."); EEOC v. Arabian Am. Oil Co., 499 U.S. 244, 260 (1991) (Scalia, J., concurring) (legislative rules distinction "anachronistic").

301. Jones v. Am. Postal Workers Union, 192 F.3d 417 (4th Cir. 1999) (applying Chevron deference to an EEOC amicus brief); Wagner Seed Co. v. Bush, 946 F.2d 918, 921 (D.C. Cir. 1991) (applying Chevron deference to a decision letter).

302. Anthony, supra note 35, at 44-48; Robert A. Anthony, Interpretive Rules, Policy Statements, Guidances, Manuals and the Like - Should Federal Agencies Use Them to Bind the Public, 41 DukE L.J. 1311, 1355-59 (1992); Alfred W. Blumrosen, The Binding Effect of Affirmative Action Guidelines, 1 LAB. LAW. 261, 267 (1985); Saunders, supra note 82, at 37482; White, supra note 2, at 87-88, 102-07.

303. See Gregory v. Ashcroft, 501 U.S. 452, 485 n.3 (1991) ("EEOC's position is not embodied in any formal issuance from the agency, such as a regulation, guideline, policy statement or administrative adjudication. Instead, it is merely the EEOC's litigating position in recent lawsuits. Accordingly, it is entitled to little, if any deference."); Saunders, supra note 82 , at 374-82. Professor Merrill advocates deference to agency interpretations, regardless of format, so long as the agency is acting as a decisionmaker and not as a party to court proceedings. Merrill, supra note 4, at 987-88, 1010.

304. 529 U.S. $576(2000)$.

305. Id. at 587. Although the Christensen Court equated interpretive guidelines with opinion letters, it did so on the apparent assumption that such guidelines were not a product of rulemaking procedures. $I d$. 
signifies the agency's intent to exercise its delegated interpretive authority ${ }^{306}$ Moreover, the benefits of agency expertise and political accountability that underlie Chevron have been served when a statutory interpretation issues after informal rulemaking procedures. ${ }^{307}$ Thus, when an agency possesses legislative rulemaking authority and has followed legislative rulemaking procedures, its interpretation is deserving of deference, whether that interpretation is expressed in a rule or in an interpretive guideline. ${ }^{308}$

The Interpretive Guidance on mitigating measures illustrates this point. The Guidance issued only after informal rulemaking procedures were followed. ${ }^{309}$ It was a direct response to comments received during

306. The EEOC has recognized this distinction. While it produces opinion letters, amicus briefs and policy guidances, the EEOC issues its Interpretive Guidelines only after following notice and comment procedures and sometimes after public hearings have occurred. See White, supra note 2, at 103-04. See also Blumrosen, supra note 302, at 267-79.

307. Saunders, supra note 82, at 374-82. In addition, as Professor Saunders notes, extending Chevron deference only to interpretations following notice and comment procedures prevents agencies from sidestepping the APA's rulemaking procedures. Id.

308. See EEOC v. Arabian Am. Oil Co., 499 U.S. 244, 260 (1991) (Scalia, J., concurring) ("In an era when our treatment of agency positions is governed by Chevron, the 'legislative rules vs. other action' dichotomy of Gilbert is an anachronism."). Moreover, as Professor Saunders has observed, when an interpretation is the product of delegated authority, it is the functional equivalent of a legislative rule and thus should issue only after notice and comment procedures have been followed. Saunders, supra note 82, at 382. See Alfred W. Blumrosen, Society in Transition IV: Affirmative Action Under the Civil Rights Act of 1991, 45 RUTGERS L. REV. 903, 910-11 (1993) (urging Chevron deference to EEOC guidelines issued after rulemaking procedures); White, supra note 2, at 105 (stating that EEOC interpretive guidelines are entitled to Chevron deference).

309. Brief for Petitioners at 13, Murphy v. United Parcel Serv., Inc., 527 U.S. 516 (1999) (No. 97-1992):

Exactly one year after the passage of the ADA, the EEOC issued final rules for enforcement of the ADA. Included with those rules was an appendix entitled "Interpretive Guidance." The EEOC followed the same notice and comment procedures in promulgating both the text of the final regulations and the Interpretive Guidance.

Id. See generally Equal Employment Opportunity for Individuals with Disabilities; Notice of Proposed Rulemaking, 56 Fed. Reg. 8586-8603 (1991) (proposed Feb. 28, 1991). In response to comments received, the mitigating measures interpretive guidance was revised to clarify "that the determination of whether an impairment substantially limits one or more major life activities is to be made without regard to the availability of medicines, assistive devices, or other mitigating measures." Americans with Disabilities Act; Implementation: Equal Employment for Individuals with Disabilities, 56 Fed. Reg. 35,727-28 (1991) (proposed July 26, 1991). See Colker, supra note 22, at 155-56 (noting that "the EEOC carefully followed standard procedures regarding notice and comment in promulgating the mitigating measures rule" and that the Supreme Court deferred to a similar guidance promulgated by HHS in the Arline case); Kamholz, supra note 22, at 104 n.47 ("[T]he EEOC's guidelines on mitigating measures deserves special deference.").

One commentator points out that the mitigating measures rule was originally included with the rule vis-à-vis impairments, not "substantial limitation." Wern, supra note 3, at 1565. He contends that the Interpretive Guidance thus fails the "notice" requirements of the APA, "even though it was amended in direct response to the comment process. Id. As this commentator concedes, however, the draft notice did contain the following example: "A diabetic who without insulin would lapse into a coma would be substantially limited because the individual can only perform major life activities with the aid of medication." Equal Em- 
the rulemaking process and clarified how the EEOC intended to analyze the statutory definition of disability. ${ }^{310}$

Thus, that the interpretation is found in an Appendix to the Regulations, issued simultaneously with those regulations, is no basis for denying the interpretation the deference to which it otherwise would be due. While format should sometimes matter in deciding whether Chevron applies, ${ }^{311}$ format was not a proper basis for denying Chevron review in the Sutton case. The agency's interpretation was a product of deliberate and informed decisionmaking, one that followed notice and comment procedures. Because the agency was exercising the authority delegated to it in a manner that conformed to the Administrative Procedures Act, the distinction between the regulation and its interpretive guidance is of no moment for Chevron purposes.

\section{The Seminole Rock Claim}

In its brief to the Court, the EEOC went one step further. It claimed a heightened deference for its Interpretive Guidance, insisting that an agency's interpretation of its own regulation is controlling on the Court unless that interpretation is arbitrary and capricious. ${ }^{312}$ For support, the EEOC cited, inter alia, the Court's opinion in Auer $v$. Robbins. ${ }^{313}$

At issue before the Court in Auer was how the Fair Labor Standards Act's "salary basis" test should be interpreted. ${ }^{314}$ The FLSA directs the Secretary of Labor to promulgate regulations "defining and delimiting" statutory exemptions from the wage/hour laws. ${ }^{315}$ The Secretary has done so, through regulations proclaiming that an employee must be paid on a "salary basis" in order to be an exempt executive, administrative or professional employee. ${ }^{316}$ In Auer, rather than engaging in its own interpretation of the salary basis test, the Court instead invited the Secretary to submit an amicus brief interpreting the

ployment Opportunity for Individuals with Disabilities; Notice of Proposed Rulemaking, 56 Fed. Reg. at 8593. The EEOC's position was contained in the proposed rule and was clarified in response to comments, which, of course, is the point of notice and comment proceedings. See Colker, supra note 22, at 154-55.

310. Americans with Disabilities Act; Implementation: Equal Employment for Individuals with Disabilities, 56 Fed. Reg. at 35,727-28.

311. See supra notes $302-304$ and accompanying text.

312. Brief for the United States and the Equal Employment Opportunity Commission as Amicus Curiae Supporting Petitioner at 17-18, Murphy v. United Parcel Serv., Inc., 527 U.S. 516 (1999) (No. 97-1992).

313. Id. (citing 519 U.S. 452 (1997)).

314. Id. at 454.

315. 29 U.S.C. $\$ 213$ (1994).

316. 29 C.F.R. $\$ 541.1(1999)$. 
regulation. ${ }^{317}$ The Court then deferred to that interpretation, labeling it "controlling" unless "plainly erroneous."

The EEOC, along with the petitioners in Sutton, urged the Court to follow Auer and to view the EEOC's Interpretive Guidance as "controlling." 319 But that view reflects a misunderstanding of Auer and of the Seminole Rock doctrine ${ }^{320}$ on which Auer was based. In Auer, the language being interpreted was "a creature of the Secretary's own regulations." ${ }^{321}$ When an agency is interpreting its own regulation, the Court has extended a particularly strong measure of deference to the agency's interpretation. ${ }^{322}$ This is particularly true when the regulation is not interpreting the statute but is filling in statutory gaps in accordance with an express legislative directive to do so. ${ }^{323}$

No such situation, however, was present in Sutton. The Interpretive Guidance was not interpreting the regulation. Rather it was interpreting the words of the statute itself. ${ }^{324}$ Thus, Sutton was a Chevron, not a Seminole Rock, case.

This understanding of the limits of the Seminole Rock doctrine obviates concerns that the EEOC could inflate the deference it is due when interpreting the ADA through use of an Interpretive Guidance, as opposed to a regulation. ${ }^{325}$ The EEOC may not ratchet up the level

317. Auer v. Robbins, 519 U.S. 452, 461 (1997).

318. Id.

319. Brief for the United States and the Equal Employment Opportunity Commission as Amicus Curiae Supporting Petitioner at 17, Murphy v. United Parcel Serv., Inc, 527 U.S. 516 (1999) (No. 97-1992); Petitioner' Brief at 16, Sutton v. United Air Lines, Inc., 527 U.S. 471 (1999) (No. 97-1943).

320. See supra notes $42-43$ and accompanying text for a discussion of the Seminole Rock form of deference.

321. Auer, 519 U.S. at 461.

322. "Because the salary-basis test is a creature of the Secretary's own regulations, his interpretation of it is, under our jurisprudence, controlling unless 'plainly erroneous or inconsistent with the regulation.' "Id. (quoting Bowles v. Seminole Rock \& Sand Co., 325 U.S. 410, 414 (1945)). See Christensen v. Harris County, 529 U.S. 576, 588 (2000) (the Auer Court extended deference to an agency brief because the Secretary was interpreting his own regulation); Shalala v. Guernsey Mem'l Hosp., 514 U.S. 87, 94-95 (1995).

323. Under the Secretary's regulation, exempt status from the minimum wage and overtime requirements of the FLSA requires that employees' salaries not be "subject to" reduction because of the quantity or quality of work. 29 C.F.R. $\$ 541.118(a)$ (1999). The operative language at issue in Auer was the phrase "subject to," which appears in the regulation, not in the statute. The regulatory test was created in response to Congress's directive to the Secretary to define the scope of exemptions for administrative, professional and executive employees. See supra note 315 and accompanying text.

324. The question before the Court in Sutton was how the phrase "substantially limits" should be construed, a term found in the statute itself. See, e.g., Sutton, 527 U.S. at 482 . The regulation and the Interpretive Guidance both attempted to flesh out the meaning of this statutory term. See supra notes 12-14 and accompanying text. This point was correctly noted in Respondent's Brief at 24, Murphy v. United Parcel Serv., Inc., 527 U.S. 516 (1999) (No. 97-1992).

325. See Manning, supra note 41 , at 618 , who criticizes the Seminole Rock doctrine as a 
of judicial deference to its interpretation of "substantially limits" (or other statutory terms such as "reasonable accommodation" or "undue hardship") by placing that interpretation in an "Interpretive Guidance" instead of in the regulation itself. ${ }^{326}$ Whether in the regulation or in the Appendix accompanying it, the agency's interpretation is of the statutory language.

Accordingly, the language at issue in Sutton, unlike in Auer, was not the agency's creature; it was instead the creature of Congress. Thus, Chevron, not Seminole Rock, was the appropriate precedent to apply. The EEOC's claim in Sutton to a more heightened form of deference to its Interpretive Guidance was misplaced, an important point to understand as further questions concerning the proper interpretation of the ADA's Title I emerge.

\section{CONCLUSION}

What was presented to the Court in Sutton was a difficult policy choice; how best to resolve the mitigating measures puzzle was an issue on which reasonable people could disagree. ${ }^{327}$ The Chevron doctrine teaches that the judiciary is not the government branch responsible for resolving such choices when Congress has delegated, expressly or by implication, interpretive authority to an administrative agency.

Moreover, the issue before the Sutton Court was one well-suited for Chevron deference. Congress had conferred substantive rulemaking authority on the EEOC, recognizing that formulation of policies affecting the disabled require the kind of expertise that administrative agencies are intended and able to supply. For these reasons, it makes sense to believe that Congress intended that policy choices implicated by implementation of the ADA be made by administrative agencies, rather than by courts. The EEOC had carefully considered the issue at hand, issuing its interpretation following notice and comment procedures. The agency's resolution of the interpretive issue was wellsupported by, and consistent with, the legislative history, and it was responsive to the unique aspects of Title I of the ADA.

The Supreme Court, however, has become accustomed to placing its own imprint on federal statutes in general and employment dis-

violation of separation of powers principles by permitting agencies to both write the law and say what the law means.

326. Professor Manning, for example, asserts that Seminole Rock encourages agencies to promulgate vague regulations and then interpret those regulations through other formats, a result that undercuts the APA's rulemaking process. Id. Those concerns, however, were not present in Sutton. The EEOC was interpreting the statute, not its regulations, and both its regulation and its Interpretive Guidance issued after notice and comment procedures had been followed. See supra notes 309-310 and accompanying text.

327. See supra note 221 and accompanying text. 
crimination laws in particular. ${ }^{328}$ The Court's employment of a textualist interpretive strategy to decide Sutton at Step One of Chevron epitomizes the way in which the Court has employed a purportedly neutral "methodology" both to disguise and to justify an increased judicial activism. The Court has been accused in the past of "breach[ing] ... political faith" by conservatively interpreting progressive civil rights statutes, ${ }^{329}$ and the Sutton decision follows this wellworn path. But that it does so in the guise of finding clear congressional meaning does a disservice to more than the law of employment discrimination. It also breaches political faith with the implied delegation doctrine underlying Chevron.

328. See supra notes $83,92-94$ and accompanying text.

329. Eskridge, supra note 83, at 684. 